\title{
Ontogeny of highly variable ceratitid ammonoids from the Anisian (Middle Triassic)
}

\author{
Eva Alexandra Bischof ${ }^{\text {Corresp., }}{ }^{1}$, Nils Schlüter ${ }^{2}$, Dieter Korn ${ }^{2}$, Jens Lehmann ${ }^{1}$ \\ ${ }^{1}$ Geowissenschaftliche Sammlung, FB5 Geowissenschaften, Universität Bremen, Bremen, Bremen, Germany \\ ${ }^{2}$ Museum für Naturkunde, Leibniz-Institut für Evolutions- und Biodiversitätsforschung, Humboldt Universität Berlin, Leibniz-Institut für Evolutions- \\ undBiodiversitätsforschung, Invalidenstraße, 43, 10115 Berlin, Germany, Berlin, Germany \\ Corresponding Author: Eva Alexandra Bischof \\ Email address: bischof@uni-bremen.de
}

Ammonoids reached their greatest diversity during the Triassic period. In the early Middle Triassic (Anisian) stage, ammonoid diversity was dominated by representatives of the family Ceratitidae. High taxonomic diversity can, however, be decoupled from their morphologic disparity. Due to its high phenotypic variability, the high diversity of ceratitids of the Anisian of Nevada was initially assumed to be caused by artificial over-splitting. This study aims to contribute data to settle this issue by applying geometric morphometrics methods, using landmarks and semi-landmarks, in the study of ontogenetic cross-sections of ammonoids for the first time. The results reveal that alterations in ontogenetic trajectories, linked to heterochronic processes, lead to the morphologic diversification of the species studied herein. Our knowledge, based on these ontogenetic changes, challenge the traditional treatment of species using solely adult characters for their distinction. This study furthermore demonstrates that the high diversity of the Anisian ammonoid assemblages of Nevada based on the traditional nomenclatoric approach is regarded to be reasonably accurate. 
1 Ontogeny of highly variable ceratitid ammonoids from 2 the Anisian (Middle Triassic)

3

4

Eva A. Bischof ${ }^{1}$, Nils Schlüter ${ }^{2}$, Dieter Korn ${ }^{2}$, Jens Lehmann ${ }^{1}$

${ }^{1}$ Geowissenschaftliche Sammlung, Fachbereich Geowissenschaften, Universität Bremen, Leobener Strasse 8, 28357 Bremen, Germany

${ }^{2}$ Naturhistorisches Forschungsinstitut, Museum für Naturkunde, Humboldt-Universität zu Berlin, Invalidenstraße 43, 10115 Berlin, Germany

Corresponding Author:

Eva Bischof ${ }^{1}$

MARUM, Leobener Strasse 8, 28359 Bremen, Germany

Email address: eva.bischof@hotmail.com

\section{Abstract}

Ammonoids reached their greatest diversity during the Triassic period. In the early Middle Triassic (Anisian) stage, ammonoid diversity was dominated by representatives of the family Ceratitidae. High taxonomic diversity can, however, be decoupled from their morphologic disparity. Due to its high phenotypic variability, the high diversity of ceratitids of the Anisian of Nevada was initially assumed to be caused by artificial over-splitting. This study aims to contribute data to settle this issue by applying geometric morphometrics methods, using landmarks and semi-landmarks, in the study of ontogenetic cross-sections of ammonoids for the first time. The results reveal that alterations in ontogenetic trajectories, linked to heterochronic processes, lead to the morphologic diversification of the species studied herein. Our knowledge, based on these ontogenetic changes, challenge the traditional treatment of species using solely adult characters for their distinction. This study furthermore demonstrates that the high diversity of the Anisian ammonoid assemblages of Nevada based on the traditional nomenclatoric approach is regarded to be reasonably accurate.

\section{Introduction}

After the Permian-Triassic mass extinction event, ammonoids flourished and spread globally to become an important part of the marine biota (House 1993; Brosse et al. 2013; Brayard \& Bucher 2015; Neige 2015). They reached their greatest generic diversity of all time in the Triassic Period (Brayard et al. 2009; Whiteside \& Ward 2011). The diversity peak in the late Anisian is dominated by genera of the family Ceratitidae (Brayard et al. 2009; supporting material fig. S2). Not least due to their wide paleogeographic distribution and high diversity as well as abundance in the fossil record, ammonoids are an excellent biostratigraphic tool. This is 
40 especially true of members of the family Ceratitidae, Mojsisovics 1879 for which many North

41 American Anisian biostratigraphic zones and subzones are named (Jenks et al. 2015; figs. 13.13, 42 13.14).

43 The fossil material used in this study was collected in the late Anisian Fossil Hill Member of the

44 Star Peak Basin in north-western Nevada, USA. The studied successions are considered to be the 45 world's most complete low-paleolatitude successions, yielding late Anisian ammonoid 46 assemblages (Monnet \& Bucher 2005). The first comprehensive taxonomic work on the Anisian 47 ammonoid communities of the famous fossil locality at Fossil Hill in the Humboldt Range was 48 published by Smith (1914) in his monograph on the North American Middle Triassic marine 49 invertebrates. According to the taxonomic practice of his time, he described or listed a total of 50110 ammonoid species from Fossil Hill. More recently, Silberling \& Nichols (1982), Bucher 51 (1992) and Monnet \& Bucher (2005) refined the original alpha taxonomy and the biostratigraphy 52 with contemporaneous methods and reduced the number to 81 valid species (Brosse et al. 2013). However, it is important to note that succeeding assemblages show a progressive shift in morphology; therefore, the cutoff between contiguous species is essentially arbitrary (Silberling 1962; Silberling \& Nichols 1982). This challenges the taxonomic concept and sheds new light on diversity patterns in general. An increasing number of studies suggest that the seemingly high diversity could in some cases be artificially inflated by taxonomic over-splitting (i.e. Kennedy \& Coban, 1976; Forey et al. 2004; De Baets et al. 2013; Knauss \& Yacobucci 2014, De Baets et al. 2015). Furthermore, taxonomic diversity and morphological disparity of Triassic ammonoids were probably decoupled (McGowan 2004, 2005; Brosse et al. 2013). At present, only a few studies have investigated trends in morphological disparity of Triassic ammonoids (Monnet et al. 2015).

Previous studies have proven that - particularly due to their accretionary planispiral conch growth with conservation of previous growth stages - ammonoids offer a high-resolution data basis for ontogenetic, developmental and also taxonomic studies. While the study of conch ontogeny has a long history in the study of Paleozoic ammonoids (e.g., Korn \& Klug 2007; Korn 2010; Monnet et al. 2011; Naglik et al. 2015), it was only rarely examined on Mesozoic ammonoids (e.g., Rieber 1962; Tajika et al. 2015; Bischof \& Lehmann 2020). So far, the morphology and ontogeny of ammonoids was mainly assessed using descriptive, comparative or traditional morphometric methods (linear measurements). In his classic work of 1966, David M. Raup introduced traditional geometric parameters for the description of coiled conch morphospace. These "Raupian parameters" were subsequently refined by Korn \& Klug (2003, 2007), Korn (2010) and Klug et al. (2015). However, the shapes of discoidal ammonoids often differ through their characteristic ways of ventral arching and presence or absence of a keel. Both characteristics can hardly be described with linear measurements (Neige 1999). Therefore, the use of traditional morphometric methods might be limited when it comes to distinguishing ceratitid species.

For the first time, the morphology and ontogeny of whorl profiles of the late Anisian ceratitids were analyzed using landmark- and semilandmarks-based geometric morphometric methods 
80 (GMM) instead of linear measurements (traditional morphometrics). This is reasoned in the 81 tremendous advantages of GMM over the latter; landmarks and semi-landmarks cover shape 82 variations of complete morphologies, which are sometimes not to be recognized or overseen with 83 linear measurements of traditional morphometrics methods (Neige 1999). In addition, GMM 84 allow the analysis of shape and size separately (Hammer \& Harper 2005; Zelditch et al. 2012; 85 Polly \& Motz 2016) and do not introduce artifactual patterns of covariation (Gerber 2017), 86 which is often the case when proportions are studied.

87 The literature on geometric morphometric analyses (landmark-based approaches and Fourier 88

89

90

91

92

93

94

95

96

97

98

99

100

101

102

103

104

105

106

107

108

109

110

111

112

113

114

115

116

117

118

119 analysis) of molluscs is rather scarce. Although important pioneering works exist, the previous studies are of limited use in an ontogenetic context because they all focus either on the shape of the whole conch or on single (isolated) ontogenetic stages (landmarks: e.g., Johnston et al. 1991; Neige \& Dommergues 1995; Reyment \& Kennedy 1998; Stone 1998; Neige 1999; Reyment 2003; Van Bocxlaer \& Schultheiß 2010; Knauss \& Yacobucci 2014; Fourier analysis: e.g., Courville \& Crônier 2005; Simon et al. 2010; Simon et al. 2011; Korn \& Klug 2012; Klein \& Korn 2014).

In order to evaluate the hitherto used taxonomic scheme, ontogenetic patterns within the family Ceratitidae and their changes over time were investigated. Working with ontogenetic crosssections allows the estimation of the relative age of the whorls, which adds an extra dimension to the analysis. The tools presented here are intended to complement traditional descriptions and to evaluate and quantify their results. This study should serve as a general motivation to conduct GMM studies on invertebrates with accretionary planispiral growth.

\section{Materials \& Methods}

Geological setting. The ammonoid material derives from the Fossil Hill Member of Fossil Hill in the Humboldt Range and Muller Canyon in the Augusta Mountains (Pershing County), northwestern Nevada, USA (Fig. 1) and is stored in the Geosciences Collection of the University of Bremen (GSUB), Germany. The material from the Wilderness Study Area of the Augusta Mountains, Pershing County was collected with permission of the U.S. Department of the Interior, Bureau of Land Management (BLM, Nevada State office, Winnemucca District). The Fossil Hill Member is a succession of alternating layers of mudstone with lenticular limestone and calcareous siltstone beds (see Fig. 2). The rich and diverse fossil content consists primarily of halobiid bivalves and ammonoids. Detailed geological and stratigraphic descriptions were published by Nichols \& Silberling (1977), Silberling \& Nichols (1982) and Monnet \& Bucher (2005).

Studied specimens. The fossil material comprises 72 ammonoid specimens of the family of Ceratitidae Mojsisovics, 1879. These represent twelve species in seven genera (Fig. 2, Tab. 1) that either belong to the subfamily Beyrichitinae Spath, 1934 or Paraceratitinae Silberling, 1962. Most of the studied species show high intraspecific variation with overlapping morphologies (see Tab. 1 and Figs. 3-5). Members of these genera (Gymnotoceras, Frechites and Parafrechites in particular) are sometimes hard to differentiate. They mainly differ in the ventral conch outline, 
120

121

122

123

124

125

126

127

128

129

130

131

132

133

134

135

136

137

138

139

140

141

142

143

144

145

146

147

148

149

150

151

152

153

154

155

156

157

158

159

ornamentation, adult ribbing and maximum growth size. The younger the individuals are, the greater the similarities. Despite their complicated taxonomy, all selected species are index fossils of the late Anisian Fossil Hill Member (see Fig. 2). It was assumed that the individual species have similar coiling rates (i.e., the individual species develop the same number of whorls in the course of their life). The total number of volutions developed by the species varies between five and a half and seven (see Tab. 1-Total number of volutions).

Preparation and data acquisition. We prepared high-precision cross-sections intersecting the protoconch of each specimen, following the methods by Korn (2010) and Klug et al. (2015). Subsequently, we scanned the polished surfaces in high resolution with a flat screen scanner to ensure that all pictures have the same scale. Thereafter, the scan images were digitized. CT scan images of Anisian ammonoids from Nevada do not provide sufficient contrast of the internal structures for a reliable analysis (Bischof \& Lehmann 2020).

Based on the digitized cross-sections, we performed a 2D landmark-based geometric morphometrics analysis. The landmarks were retrieved in tpsDig2 v.2.31 (Rohlf 2010). Sixteen landmarks were digitized per half whorl (i.e. whorl stage), which resulted in 176 landmarks per specimen (16 landmarks on 11 half whorls; Fig. 6). This set of landmarks consists of two single $(1,2)$ and 7 pairs of landmarks $(3-16)$, of which eight are sliding semi-landmarks. Whereas landmarks are discrete anatomical loci (i.e. point of highest curvature of venter), sliding semilandmarks are placed along a curve (or a surface) between two landmarks in a way that best describes the curvatures of the outline. In a second step, an algorithmic approach optimizes the approximation of the outline (Zelditch 2012). In order to omit missing values in subsequent analyses, the data set was limited to whorl stage number 5.5. From a methodological point of view, it is more practical to rotate the shells by $90^{\circ}$ compared to conventional illustrations (cf. Stridsberg 1990) into a lying position. Since ammonoid conchs are spiral-shaped, each whorl is cut in two parts when preparing the cross sections (see Fig. 6). The half whorls on the left side of the protoconch have odd numbers ("odd whorls"; here 0.5-5.5 and those on the right side have even numbers ("even whorls"; here 1.05.0 "). Homologous landmarks were set in accordance to the axial plane.

Calculation of Procrustes shape. All geometric morphometric analyses were carried out using the R software v 3.6.3. (R Core Team 2020) packages Morpho v2.8 (Schlager 2017), geomorph v3.3.1. (Adams et al. 2020) and RRPP v0.6.0 (Collyer \& Adams 2018; Collyer \& Adams 2020). Plots were drawn with the R package ggplot2 (Wickham 2016). Using the Morpho::procSym function, the 2D landmark coordinates were subjected to a full generalized Procrustes alignment (GPA). The semilandmarks were slid minimizing Procrustes distance. The full Procrustes fit standardizes size, orientation and position, leaving only the Procrustes shape coordinates (Bookstein 1991, chap. 7.1, p. 258-270; Hammer \& Harper 2005; Zelditch et al. 2012). Since the "odd" and "even" whorls cannot be made congruent by any of these operations (i.e. alignment, translation, rotation), all "even" whorls were manually mirrored before the GPA.

The individual whorls were regarded as different structures of the ammonoid conch. Therefore, the GPA was performed separately for every whorl. The procSym function performs Procrustes 
160

161

162

163

164

165

166

167

168

169

170

171

172

173

174

175

176

177

178

179

180

181

182

183

184

185

186

187

188

189

190

191

192

193

194

195

196

197

198

199

superimposition including sliding of semi-landmarks on curves and accounts for the symmetry of the object. Subsequently, the R function geomorph::combine.subsets was used to normalize the configurations of all whorl stages to unit centroid size or with a customized weighting (see "Developmental morphospaces"). The centroid size (CS) is regarded as a proxy for the size of the whorls and equals the square root of the summed squared distances of each landmark from the centroid of the landmark configuration before the GPA (Zelditch et al. 2012). The function geomorph::combine.subsets was originally introduced to combine different parts of a body (e.g., heads and tails; Collyer et al. 2020).

To visualize the multivariate data in two-dimensional morphospaces, we ran a Principal Component Analysis (PCA) on the aligned Procrustes shape coordinates using the R function stats::prcomp. Thereby we used two different types of morphospaces: Ontogenetic and developmental morphospaces.

Ontogenetic trajectory spaces. It is well-known that ammonoids have a very characteristic but also complex ontogenetic development (e.g., Klug 2001). To visualize the ontogenetic development of ammonoids, there are different types of morphospaces. Ontogenetic trajectory spaces (originally called ontogenetic morphospaces), as defined by Bischof \& Lehmann (2020, p.2), illustrate the differences in total ontogenetic development of individuals. They show the data in an artificial state of combined morphologies of different ontogenetic stages. To calculate an ontogenetic trajectory space, all Procrustes shapes (i.e. whorls) of an individual are reassembled before running the Principal Component Analysis. This means that, in an ontogenetic trajectory space, the ontogenetic trajectory of every individual is reduced to a single data point. Ontogenetic trajectory spaces are a tool to examine if the ontogenetic pathways of individuals differ, but they do not show how the trajectories vary. To test whether ontogenetic trajectories statistically differ between species, a multivariate analysis of variance (MANOVA) using the R function stats::manova was applied.

Developmental morphospaces. Developmental morphospaces as defined by Eble (2003, p. 40) are morphospaces that directly contain developmental information. In terms of this study, this means that every individual dot in the morphospace reflects a specific ontogenetic stage (i.e. half whorl) of an individual. By connecting all points of an individual, its ontogenetic trajectory can be obtained. In contrast to ontogenetic trajectory spaces, developmental morphospaces show how individual whorls differ from each other.

General Procrustes Analysis (GPA) removes all information about size from a given set of data leaving only the pure shape coordinates. However, as can be seen in Figure 6, size differences between different whorl stages are tremendous. If normalized to unit centroid size (i.e. nonweighted morphospace), the earliest whorls of ammonoids therefore get enormously enlarged and the last whorls scaled down. In general, deviations (measurement uncertainties as well as actual morphological variation) are increased for the initial whorls and reduced for older whorl stages. Therefore, a second morphospace with weighted Procrustes shape coordinates was calculated. Thereby, the logarithmic centroid size $\left(\log _{10} \mathrm{CS}\right)$ of all configurations of a whorl stage were normalized to the proportional centroid size of the respective stage to the sum of all whorl 
200 stages $\left(\log _{10} \mathrm{CS}_{\text {whorl i }} / \sum \log _{10} \mathrm{CS}_{\text {whorls }}\right)$. The principal components of the PCA on the weighted 201 shapes were called wPC (weighted principal components).

202 If the relative $\log _{10} \mathrm{CS}$ is used to normalize the centroid size of the configurations, this approach 203 is extremely similar to a Relative Warp Principal Component Analysis (RW-PCA; size-shape 204 space) after Mitteroecker et al. (2004). To calculate a RW-PCA the shape matrix of a 205 configuration is augmented by an additional column containing information about the $\log _{10} \mathrm{CS}$ of 206 the configurations. Whereas the R function geomorph::combine.subsets scales every 207 configuration accordingly, the size information in the RW-shape matrices are stored in the 208 additional variable. The resulting RW size-shape space can be analyzed with an ordinary PCA. 209 Typically, RW size-shapes spaces are strongly dominated by the $\log _{10} \mathrm{CS}$ and PC1 therefore 210 often accounts for more than $90 \%$ of the variation. If proportional $\log _{10} \mathrm{CS}$-values

$211\left(\log _{10} \mathrm{CS}_{\text {configuration } \mathrm{i}} / \sum \log _{10} \mathrm{CS}_{\text {configurations }}\right)$ are used, the analysis is less dominated by size, but the 212 eigenvalues are very similar to the ones of the weighted PCA (wPCA). For simplicity the R 213 function was used here.

214 Because weighting does not change the shapes itself, weighted and non-weighted developmental 215 morphospaces look very similar. The main difference is the placement of the individual 216 configurations within the morphospace. Whether weighted or non-weighted shape coordinates 217 should be used, depends on what the analysis is intended to show. A summary of the three 218 different approaches how to combine landmark configurations can be found in Table 2.

219 To model the shapes at the maximum and minimum PC-values, the $\mathrm{R}$ function

220 GeometricMorphometricsMix::reversePCA (Fruciano 2019) was used. The function is designed 221 to recalculate artificial Procrustes shape variables from the extreme PC-values in a morphospace.

222 The thin-plate spline deformation grids were calculated using the $\mathrm{R}$ function

223 geomorph::plotRefToTarget.

224 Trajectory analysis. In morphometric studies, ontogenetic trajectories represent a series of 225 measurement values of different ontogenetic stages of an individual or a group, called 226 longitudinal data (Klingenberg 1998). To quantify the differences of the ontogenetic trajectories 227 of the individual species, the $\mathrm{R}$ function RRPP::trajectory.analysis with 999 iterations was used.

228 The function calculates a linear model with at least one categorical interaction variable (here:

229 Shape $\sim$ Species * WhorlStage) and assesses differences in path distance (magnitude differences, 230 length of trajectories), trajectory shape and the angle between the individual trajectories 231 (trajectory correlation) (Collyer \& Adams 2013).

232 If weighted shape-coordinates were used, the artificial size-shape relationship could overlay true 233 differences between the trajectories. Therefore, only non-weighted shape coordinates were 234 analyzed in the trajectory analysis.

235

\section{Results}

237 Ontogenetic trajectory spaces. Ontogenetic trajectory spaces are means to visualize whether or 238 not the ontogenetic development of two or more individuals differs. The first three components 239 (PCs) of the Principal Component Analysis (PCA) on the shape coordinates with combined 
240

241

242

243

244

245

246

247

248

249

250

251

252

253

254

255

256

257

258

259

260

261

262

263

264

265

266

267

268

269

270

271

272

273

274

275

276

277

278

279

ontogenetic stages of an individual account for $58.3 \%\left(\mathrm{PC}_{1}=38.3 \%, \mathrm{PC}_{2}=13.4 \%, \mathrm{PC}_{3}=6.6\right.$ $\%$ ) of the total variation. Especially considering that there are a total of 352 primary components (x and y coordinates of 176 landmarks), but only 72 specimens, this result can be regarded as satisfactory. The convex hulls of the ontogenetic trajectory space of most species reveal a large overlap (Fig. 7). Nevertheless, the ontogenetic trajectory spaces differ significantly between species (MANOVA: Pillai's trace $=9.8962 ; \sim \mathrm{F}(1,11)=1.6437, \mathrm{p}<0.001$ ).

Since PC1 accounts for $38.3 \%$ of the total variation, the most important characteristic is the position of the individuals on the x-axis. In fact, there are certain species that primarily have negative PC1 values (B. vogdesi, F. nevadanus, F. occidentalis, M. spinifer, P. meeki) and some that are more restricted to positive PC1 values (G. blakei, G. mimetus, G. rotelliformis, $G$. weitschati, P. dunni). B. cordeyi and D. lawsoni, both cover a wider range of different PC1 values, but are generally restricted to negative PC2 and positive PC3 values.

Non-weighted developmental morphospace occupation. The first three components of the PCA on the non-weighted shape space account for $93.8 \%\left(\mathrm{PC}_{1}=78.5 \%, \mathrm{PC}_{2}=11.5 \%, \mathrm{PC}_{3}=\right.$ $3.1 \%$ ) of the total variation. The PCA plot (Fig. 8) of PC1 and PC2 shows that the whorls of early ontogenetic stages cover the lower left quadrant of the morphospace (negative PC1 and PC2 values), which characterizes extremely depressed, broad whorls with a flat venter (Fig. 9A). The center of the morphospace (PC1 equals 0 and PC2 is positive) is occupied by intermediate growth stages (juveniles), which have a more quadratic outline with an only slightly triangular venter (Fig. 9B). The lower right quadrant (high PC1 and low PC2 values) is associated with the latest ontogenetic stages (adults). Towards maturity, the whorls increase mainly in height and have a clearly triangular venter and sometimes a keel (Figs. 9C, 10). Overall, there are two extreme adult shapes: Type (A) describes rather depressed, stout conchs with only a slight overlap with the preceding whorl and are associated with much shorter ontogenetic trajectories. Type (B) describes compressed conchs with a clearly triangular venter and a higher degree of overlap and are associated with longer ontogenetic trajectories. For the assignment of the species to the two types see Table 3 .

The developmental morphospace of beyrichitine and paraceratitine ammonoids comprises three basic shape stages, which are not separated by sharp borders (Figs. 9): 1) Earliest whorls: broad and very flat; 2) Juveniles: more rounded and depressed; 3) Adults: mostly high and compressed whorls. Since type A species stop their development at more rounded and depressed whorls, their adult whorls resemble the juvenile stages of type B (Fig. 10).

Ontogenetic trajectories in the non-weighted developmental morphospace. The ontogenetic trajectories of species in the non-weighted developmental morphospace share many similarities: They all have similar directions of propagation and a slight parabolic shape (Fig. 8). The variation detected by the trajectory analysis ( $\mathrm{R}$ function RRPP::trajectory.analysis) revealed significant differences in trajectory length (path distance), trajectory shape and trajectory slope between most species (Additional file 1, summarized results below).

Members of the type A ontogeny have smaller magnitudes of shape change and different trajectory shapes than members from type B ontogeny (path distances A: 0.2005-0.0225; B: 
280

281

282

283

284

285

286

287

288

289

290

291

292

293

294

295

296

297

298

299

300

301

302

303

304

305

306

307

308

309

310

311

312

313

314

315

316

317

318

0.2276-0.2778). For the assignment of the species to the two types see Table 3. Only pairwise differences of the path distance and the trajectory shape between type A and type B species are statistically significant (magnitude of shape change: 17 / 66 possible pairs; trajectory shape: 16 / 66 possible pairs).

Most species have statistically significant pairwise differences in trajectory slope (57 / 66 possible pairs). Species of all pairs with non-significant pairwise p-values are in the same ontogenetic group (i.e. both belong to type A or B). The trajectories of the nine pairs with nonsignificant differences in slope, have non-significant magnitudes and shapes also. However, none of the species that share a common slope have overlapping biostratigraphic ranges.

Weighted developmental morphospace occupation. The first three components of the PCA on the weighted shape space account for $94.8 \%\left(\mathrm{wPC}_{1}=85.8 \%, \mathrm{wPC}_{2}=7 \%, \mathrm{wPC}_{3}=3.0 \%\right)$ of the total variation. In comparison to the regular PCA, the wPCA is - by definition - more strongly controlled by the centroid size of the configurations, which is mainly expressed by the domination of PC1.

Similar to the regular PCA plot (Fig. 8), the wPCA morphospace (Fig. 11) can be divided into three main parts: 1) The extremely depressed earliest whorls cover the lower left quadrant (low $\mathrm{PC} 1$ and PC2 values); 2) the center of the plot (PC1 equals $0, \mathrm{PC} 2$ positive) is occupied by the more depressed whorls of juveniles and 3) adult whorls are associated with positive PC1 values. In contrast to the PCA, the wPCA reveals a more distinct separation of the type A and type B groups of adult whorls (see Tab. 3). Representatives of the more depressed type B clearly occupy the lower right quadrant (positive PC1 and negative PC2 values). This division into type A and B can also be seen in the mean shapes of the whorl 5.5 of the respective species (Fig. 10).

\section{Discussion}

Members of the family Ceratitidae show high intraspecific variation and strongly overlapping morphospaces (Tab. 1, Figs. 3-5). The ornamentation, which is often regarded as essential for the description of Mesozoic ammonoid groups (Klug et al. 2015), is not a unique characteristic among the family Ceratitidae. A better feature to delineate the ceratitids studied here appears to be the shape of the whorl section. The latter, however, cannot be quantified adequately by traditional morphometric methods (Neige 1999). Accordingly, the utility of conventional taxonomic and morphological methods is limited in this regard. Here, we utilize landmarks and semi-landmarks on ontogenetic cross-sections. Since previous geometric morphometric studies on mollusks all focus either on conch shape or on single (isolated) ontogenetic stages (landmarks: e.g., Johnston et al. 1991; Neige \& Dommergues 1995; Reyment \& Kennedy 1998; Stone 1998; Neige 1999; Reyment 2003; Van Bocxlaer \& Schultheiß 2010; Knauss \& Yacobucci 2014; Fourier analysis: e.g., Courville \& Crônier 2005; Simon et al. 2010; Simon et al. 2011; Korn \& Klug 2012; Klein \& Korn 2014) they cannot be regarded as ontogenetic studies. This study, investigates the use of geometric morphometric methods (GMM) with respect to their usefulness in ontogenetic developmental studies and taxonomic descriptions. 
319 Ontogenetic patterns in Ceratitidae. The ontogenetic trajectories of the studied species 320 comprise the biphasic development from strongly depressed to weakly depressed to compressed

321

322

323

324

325

326

327

328

329

330

331

332

333

334

335

336

337

338

339

340

341

342

343

344

345

346

347

348

349

350

351

352

353

354

355

356

357

358 whorl profiles (Figs. 8-11). It is commonly accepted that sudden changes in ontogenetic allometry often mark the onset of sexual maturity (i.e. Kullmann \& Scheuch 1970; Klug 2001; Klug et al. 2015).

The studied species can be divided into two main ontogenetic groups: Type (A) Truncated trajectories that are associated with depressed adult whorls; type (B) longer, complete trajectories that lead to a compressed adult whorl shape. The process of lengthening and shortening of the trajectories (i.e. related to changes in rate and timing of the development) account for the ontogenetic differentiation of the species in focus. This contrasts a previous traditional morphometric analysis by Bischof \& Lehmann (2020) of ptychitids, which revealed that the spherocone-cadicone morphospace is much more distinct. The highly ontogenetically differentiated genus Ptychites directly differed through characteristic ontogenetic trajectories. While precise temporal growth rates of ammonoids are unknown (Lécuyer \& Bucher 2006; Knauss \& Yacobucci 2014), a basic assumption herein was that the individual species have similar coiling rates (i.e., the individual species develop the same number of whorls in the course of their life). Modified rate/timing of shape change from any ancestor to any descendent within an evolutionary framework is called heterochrony (Zelditch et al. 2012, p.317). Between type A and type B species, interspecific variation of the species in focus arises from an acceleration, a special case of peramorphosis; (for discussion of this term, see Alberch et al. 1979; McNamara 2012) that allows type B species to occupy an extended portion of the morphospace characterized by more compressed whorls. Therefore, the studied ceratitids do not primarily differ in shape, but rather in the timing of the development of individual shapes. Heterochrony as a mechanism in macroevolution is known to be a key driving factor in phenotypic diversification (e.g., Gould 1977; Alberch et al. 1979; McKinney \& McNamara 1991; Gerber et al. 2007;

Gerber 2011; Korn et al. 2013; Knauss \& Yacobucci 2014). The quantification of patterns of morphologic disparity and the relationship between size and shape (i.e. heterochrony) will be the subject of future studies.

Anisian ammonoid diversity. It is widely agreed that ammonoid diversity reached its maximum during the Triassic period (House 1993; Brayard et al. 2009; Whiteside \& Ward 2011). Thereby, the late Anisian ammonoid diversity peak was dominated by members of the family Ceratitidae (Brayard et al. 2009; supporting material fig. S2). However, there is a growing number of studies critically questioning diversity peaks by arguing that - to some extent - the high diversity might be artificially inflated by taxonomic over-splitting (Forey et al. 2004; De Baets et al. 2013; Knauss \& Yacobucci 2014).

The results obtained here do justice to the general opinion that ontogenetic trajectories can be a powerful tool to describe (e.g., Korn \& Klug 2007) and discriminate ammonoid species (e.g., Rieber 1962; Bischof \& Lehmann 2020): The newly introduced methods succeeded in statistically discriminating the ontogenetic pathways of the pre-defined ceratitid species. Based on this analysis, the high diversity of the Anisian ammonoid assemblages of Nevada appears not 
359

360

361

362

363

364

365

366

367

368

369

370

371

372

373

374

375

376

377

378

379

380

381

382

383

384

385

386

387

388

389

390

391

392

393

394

395

396

397

to be artificially inflated and the alpha taxonomy is regarded to be adequate. However, the high morphological resemblances of the investigated species cannot be denied. Therefore, this study supports the main idea of McGowan (2004), McGowan (2005) and Brosse et al. (2013) that taxonomic diversity and morphological disparity need not necessarily be closely linked.

It is important to be aware of the fact that GMM carry no direct biological information. They help to understand if and how configurations differ, but not what the underlying mechanisms for their morphological development are. In the complex discoidal morphospace landmark-based approaches have proven to be useful to evaluate a priori defined taxonomic groups. Nevertheless, geometric morphometric methods cannot be considered as being a phylogenetic or taxonomic tool per se. But they certainly represent an improvement and valuable supplement to traditional methods.

Why it is worth the effort. There is no doubt that preparation and analysis of ontogenetic cross sections involves a lot of work (Korn 2012). However, geometric morphometric methods (GMMs) open the door to a new world of objectified, statistically quantifiable descriptions. For example, in the case of the fauna described herein, conventional descriptions and traditional morphometric methods did not succeed to differentiate species adequately. Landmarks and semilandmarks, however, make it possible to statistically quantify shape variations of entire morphologies (Neige 1999) and allow the analysis of shape and size separately (Hammer \& Harper 2005).

The high resolution of the ontogenetic trajectories of the herein studied material was achieved owing to the accretionary planispiral growth of ammonoids with conservation of previous growth stages (Korn 2012), which adds an intuitive, relative time-component to the ontogenetic analysis. Even though it is likely that small-scale ontogenetic changes are overlooked at a measurement density of one measurement per 180 degrees, it can be assumed that no major developmental steps were skipped (Tajika \& Klug 2020). Leaving out complete ontogenetic stages would most likely prevent the recognition of ontogenetic processes such as heterochrony. If, for example, only the earliest and latest stages of the ceratitid development were analyzed, representatives of type A and type B would differ fundamentally. The accretionary growth of many ammonoid conchs therefore not only adds an individual time component to the analysis, but more importantly ensures that no major developmental steps have been overlooked. This reinforces the general opinion that ontogenetic trajectories of ammonoids are a powerful tool to study evolutionary processes.

\section{Conclusions}

The Anisian ammonoid diversity peak was dominated by the family Ceratitidae (Brayard et al. 2009; supporting material fig. S2). However, the investigated ceratitid species show high intraspecific variation and sometimes completely overlapping morphospaces. Using conventional methods, ceratitids are often difficult to distinguish. It was therefore assumed that the high Anisian diversity in Nevada might be artificially inflated by taxonomic over-splitting. 
398

399

400

401

402

403

404

405

406

407

408

409

410

411

412

413

414

415

416

417

418

419

420

421

422

423

424

425

426

427

428

429

430

431

432

433

434

435

436

437

438

Using a landmark-based geometric morphometric approach, this study succeeded in differentiating the ontogenetic growth of the pre-defined taxonomic entities in the fossil material from the late Anisian Fossil Hill Member in Nevada, USA. Based on the findings of this study, the high Anisian ammonoid diversity in western North America appears not to be unreasonably inflated. In this context, this study furthermore supports the hypothesis that taxonomic diversity and morphologic disparity of Triassic ammonoids were decoupled (Brosse et al. 2013; McGowan 2004; McGowan 2005). The largest interspecific differences of ceratitids are the result of alterations of the ontogenetic trajectories that are likely linked to heterochronic processes (i.e. differences in timing of ontogenetic changes). This means that the individual species of this group are not solely defined by the morphology they attain at a certain growth stage, but rather by the sum and timing of all of their ontogenetic stages. The statistical quantification of the relationship between size and shape (i.e. heterochrony) will be the subject of future studies. These processes make an ad hoc distinction of the different species particularly challenging.

For a reliable traditional taxonomic identification of the species herein, it is necessary to have several individuals (Silberling 1962) with different ages of the same species from the same stratum. It has furthermore proven to be essential to analyze morphological variation of ceratitids not only between species but also across different ontogenetic stages. Therefore, the significance of ontogenetic studies on ammonoids with regard to taxonomic implications cannot be dismissed. The geometric morphometric methods introduced herein represent a big leap towards more quantitative and objective taxonomic descriptions of ammonoids.

\section{Acknowledgements}

We would like to thank D. Kuhlmann (now Messel, Germany) as former technician of the Geowissenschaftliche Sammlung Bremen for mechanical preparation of the material collected by our working group. M. Krogmann (Bremen, Germany) is thanked for his broad support in the artwork for this article. We are indebted to K. Boos for statistical support and the introduction to the R software. P. Embree (Orangevale, CA, USA) is thanked for broad support, including organization of field-campaigns, scientific information and the permission to collect on his private property. We thank the U.S. Department of the Interior, Bureau of Land Management (BLM, Nevada State office, Winnemucca District) for permission to collect samples in the Wilderness Study Area of the Augusta Mountains, Pershing County. Our gratitude goes to the reviewers Christian Klug and Kenneth De Baets and the editor Brandon Hedrick for their corrections and suggestions that greatly improved the manuscript.

\section{References}

Adams DC, Collyer ML, and A. K. 2020. Geomorph: Software for geometric morphometric analyses. R package version 3.2.1. https://cran.r-project.org/package=geomorph.

Alberch P, Gould SJ, Oster GF, and Wake DB. 1979. Size and shape in ontogeny and phylogeny. Paleobiology 5:296-317.

Bischof EA, and Lehmann J. 2020. Ontogenetic analysis of Anisian (Middle Triassic) ptychitid ammonoids from Nevada, USA. Journal of Paleontology 94:829-851. 
439

440

441

442

443

444

445

446

447

448

449

450

451

452

453

454

455

456

457

458

459

460

461

462

463

464

465

466

467

468

469

470

471

472

473

474

475

476

477

478

479

480

481

482

483

484

485

486

487

488

489

Bookstein F. 1991. Morphometric tools for landmark data: Geometry and biology. New York: Cambridge Univ. Press. p 435.

Brayard A, and Bucher H. 2015. Permian-Triassic extinctions and rediversifications. In: Klug C, Korn D, De Baets K, Kruta I, and Mapes RH, eds. Topics in Geobiology. Dordrecht, Springer: 465-473.

Brayard A, Escarguel G, Bucher H, Monnet C, Brühwiler T, Goudemand N, Galfetti T, and Guex J. 2009. Good genes and good luck: Ammonoid diversity and the End-Permian mass extinction. Science 325:1118-1121.

Brosse M, Brayard A, Fara E, and Neige P. 2013. Ammonoid recovery after the PermianTriassic mass extinction: a re-exploration of morphological and phylogenetic diversity patterns. Journal of the Geological Society 170:225-236.

Bucher H. 1992. Ammonoids of the Shoshonensis Zone (Middle Anisian, Middle Triassic) from northwestern Nevada (USA). Jahrbuch der Geologischen Bundesanstalt Wien 135:425465.

Collyer ML, and Adams DC. 2013. Phenotypic trajectory analysis: comparison of shape change patterns in evolution and ecology. Hystrix 24:75.

Collyer ML, and Adams DC. 2018. RRPP: An R package for fitting linear models to highdimensional data using residual randomization. Methods in Ecology and Evolution 9:1772-1779.

Collyer ML, and Adams DC. 2020. RRPP: Linear model evaluation with randomized residuals in a permutation procedure. Available at https://cran.r-project.org/web/packages/RRPP.

Collyer ML, Davis MA, and Adams DC. 2020. Making heads or tails of combined landmark configurations in geometric morphometric data. Evolutionary Biology:1-13.

Courville P, and Crônier C. 2005. Diversity or disparity in the Jurassic (Upper Callovian) genus Kosmoceras (ammonitina): A morphometric approach. Journal of Paleontology 79:944953.

De Baets K, Klug C, and Monnet C. 2013. Intraspecific variability through ontogeny in early ammonoids. Paleobiology 39:75-94.

De Baets K, Bert D, Hoffmann R, Monnet C, Yacobucci MM, and Klug C. 2015. Ammonoid intraspecific variability. In: Klug C, Korn D, De Baets K, Kruta I, and Mapes RH, eds. Topics in Geobiology. Dordrecht: Springer, 359-426.

Eble GJ. 2003. Developmental morphospaces and evolution. In: Crutchfield JP, and Schuster PM, eds. Santa Fe Institute Studies on the Sciences of Complexity: Oxford University Press, 33-63.

Forey PL, Fortey RA, Kenrick P, and Smith AB. 2004. Taxonomy and fossils: a critical appraisal. Philosophical Transactions of the Royal Society of London Series B: Biological Sciences 359:639-653.

Fruciano C. 2019. GeometricMorphometricsMix: Miscellaneous functions useful for geometric morphometrics. R package version 0.0.7.9000.

Gabb WM. 1864. Paleontology of California. Description of the Triassic fossils of California and the adjacent territories. Philadelphia: California Geological Survey, Paleontology:17-35.

Gerber S. 2011. Comparing the differential filling of morphospace and allometric space through time: the morphological and developmental dynamics of Early Jurassic ammonoids. Paleobiology 37:369-382.

Gerber S. 2017. The geometry of morphospaces: lessons from the classic Raup shell coiling model. Biological Reviews 92:1142-1155.

Gerber S, Neige P, and Eble GJ. 2007. Combining ontogenetic and evolutionary scales of morphological disparity: a study of early Jurassic ammonites. Evolution \& Development 9:472-482.

Gould SJ. 1977. Ontogeny and phylogeny. Cambridge, Massachusetts: Harvard University Press:1-501.

Peer] reviewing PDF | (2020:10:54008:2:0:NEW 14 Jan 2021) 
490

491

492

493

494

495

496

497

498

499

500

501

502

503

504

505

506

507

508

509

510

511

512

513

514

515

516

517

518

519

520

521

522

523

524

525

526

527

528

529

530

531

532

533

534

535

536

537

538

539

540

Hammer $\varnothing$, and Harper D. 2005. Paleontological data analysis. 2 ed. Cambridge, Blackwell:1368.

House MR. 1993. Fluctuations in ammonoid evolution and possible environmental controls. In: House MR, ed. Systematics Association Special Volume. Oxford, Clarendon Press:1334.

Jenks JF, Monnet C, Balini M, Brayard A, and Meier M. 2015. Biostratigraphy of Triassic ammonoids. In: Klug C, Korn D, De Baets K, Kruta I, and Mapes RH, eds. Topics in Geobiology. Dordrecht: Springer, 329-388.

Johnston MR, Tabachnick RE, and Bookstein FL. 1991. Landmark-based morphometrics of spiral accretionary growth. Paleobiology:19-36.

Kennedy WJ, and Cobban WA. 1976. Aspects of ammonite biology, biogeography, and biostratigraphy. Special Papers in Palaeontology 17:94.

Klein C, and Korn D. 2014. A morphometric approach to conch ontogeny of Cymaclymenia and related genera (Ammonoidea, Late Devonian). Mitteilungen aus dem Museum für Naturkunde in Berlin Fossil Record 17:1-32.

Klingenberg CP. 1998. Heterochrony and allometry: the analysis of evolutionary change in ontogeny. Biological Reviews 73:79-123.

Klug C. 2001. Life-cycles of some Devonian ammonoids. Lethaia 34:215-233.

Klug C, Korn D, Landman N, Tanabe K, De Baets K, and Naglik C. 2015. Describing ammonoid conchs. In: Klug C, Korn D, De Baets K, Kruta I, and Mapes RH, eds. Topics in Geobiology. Dordrecht: Springer, 30-24.

Klug C, Zatoń M, Parent H, Hostettler B, and Tajika A. 2015. Mature modifications and sexual dimorphism. In: Klug C, Korn D, De Baets K, Kruta I, and Mapes RH, eds. Topics in Geobiology. Dordrecht: Springer, 253-320.

Knauss MJ, and Yacobucci MM. 2014. Geographic Information Systems technology as a morphometric tool for quantifying morphological variation in an ammonoid clade. Palaeontologia Electronica 17:1-27.

Korn D. 2010. A key for the description of Palaeozoic ammonoids. Fossil Record 13:5-12.

Korn D. 2012. Quantification of ontogenetic allometry in ammonoids. Evolution \& Development 14:501-514.

Korn D, Bockwinkel J, Ebbighausen V, and Walton SA. 2013. Rare representatives in the ammonoid fauna from Büdesheim (Cephalopoda, Eifel, Late Devonian) and the role of heterochrony. Neues Jahrbuch für Geologie und Paläontologie-Abhandlungen 269:111124.

Korn D, and Klug C. 2003. Morphological pathways in the evolution of Early and Middle Devonian ammonoids. Paleobiology 29:329-348.

Korn D, and Klug C. 2007. Conch form analysis, variability, morphological disparity, and mode of life of the Frasnian (Late Devonian) ammonoid Manticoceras from Coumiac (Montagne Noire, France). In: Landman N, Davis RA, and Mapes RH, eds. Dordrecht: Springer:57-85.

Korn D, and Klug C. 2012. Palaeozoic ammonoids-diversity and development of conch morphology. Earth and life: Springer:491-534.

Kullmann J, and Scheuch J. 1970. Wachstums-Änderungen in der Ontogenese paläozoischer Ammonoideen. Lethaia 3:397-412.

Lécuyer C, and Bucher H. 2006. Stable isotope compositions of a late Jurassic ammonite shell: a record of seasonal surface water temperatures in the southern hemisphere? eEarth Discussions 1:1-19.

McGowan AJ. 2004. Ammonoid taxonomic and morphologic recovery patterns after the Permian-Triassic. Geology 32:665-668.

McGowan AJ. 2005. Ammonoid recovery from the Late Permian mass extinction event. Comptes Rendus Palevol 4:517-530. https://doi.org/10.1016/j.crpv.2005.02.004

Peer) reviewing PDF | (2020:10:54008:2:0:NEW 14 Jan 2021) 
541

542

543

544

545

546

547

548

549

550

551

552

553

554

555

556

557

558

559

560

561

562

563

564

565

566

567

568

569

570

571

572

573

574

575

576

577

578

579

580

581

582

583

584

585

586

587

588

589

590

McKinney ML, and McNamara KG. 1991. Heterochrony. The Evolution of Ontogeny. New York: Springer Science+Business Media, LLC:1-437.

McNamara KJ. 2012. Heterochrony: the evolution of development. Evolution: Education and Outreach 5:203-218.

Meek FB. 1877. Part I. Palæontology. In: King C, editor. Washington: Government Printing Office: 1-197.

Mitteroecker P, Gunz P, Bernhard M, Schaefer K, and Bookstein FL. 2004. Comparison of cranial ontogenetic trajectories among great apes and humans. Journal of Human Evolution 46:679-698.

Mojsisovics Ev. 1879. Vorläufige kurze Übersicht der Ammoniten-Gattungen der mediterranen und juvavischen Trias. Verhandlungen der Kaiserlich-Königlichen Geologischen Reichsanstalt Wien:133-143.

Mojsisovics Ev. 1888. Über einige japanische Trias-Fossilien. Vienna: Alfred Holder, K.K. Hofund Universtitäts-Buchhändler:163-178.

Monnet C, Brayard A, and Brosse M. 2015. Evolutionary trends of Triassic ammonoids. In: Klug C, Korn D, De Baets K, Kruta I, and Mapes RH, eds. Topics in Geobiology. Dordrecht: Springer:25-50.

Monnet C, and Bucher H. 2005. New Middle and Late Anisian (Middle Triassic) ammonoid faunas from Northwestern Nevada (USA): Taxonomy and biochronology. Fossils and Strata 52:1-121.

Monnet C, De Baets K, and Klug C. 2011. Parallel evolution controlled by adaptation and covariation in ammonoid cephalopods. BMC Evolutionary Biology 11 (115):1-21.

Naglik C, Monnet C, Goetz S, Kolb C, De Baets K, Tajika A, and Klug C. 2015. Growth trajectories of some major ammonoid sub-clades revealed by serial grinding tomography data. Lethaia 48:29-46.

Neige P. 1999. The use of landmarks to describe ammonite shape. In: Olóriz F, and RodríguezTovar FJ, eds. Advancing Research an Living and Fossil Cepha/opods. New York: Kluwer Academic/Plenum:263-272.

Neige P. 2015. Events of Increased Biodiversity: Evolutionary Radiations in the Fossil Record. London \& Oxford: ISTE Press Elsevier:1-152.

Neige P, and Dommergues J-L. 1995. Morphometrics and phenetic versus cladistic analysis of the early Harpoceratinae (Pliensbachian ammonites). Neues Jahrbuch für Geologie und Paläontologie, Abhandlungen 196:411-438.

Nichols KM, and Silberling NJ. 1977. Stratigraphy and depositional history of the Star Peak Group (Triassic), northwestern Nevada. Special Paper Geological Society of America 178:1-73.

Polly PD, and Motz GJ. 2016. Patterns and processes in morphospace: geometric morphometrics of three-dimensional objects. The Paleontological Society Papers 22:7199.

R Core Team. 2020. R: A Language and Environment for Statistical Computing. Version 3.6.3.Vienna, Austria: R Foundation for Statistical Computing.

Raup DM. 1966. Geometric analysis of shell coiling: general problems. Journal of Paleontology 40:1178-1190.

Reyment RA. 2003. Morphometric analysis of variability in the shell of some Nigerian Turonian (Cretaceous) ammonites. Cretaceous Research 24:789-803.

Reyment RA, and Kennedy WJ. 1998. Taxonomic recognition of species of Neogastroplites (Ammonoidea, Cenomanian) by geometric morphometric methods. Cretaceous Research 19:25-42.

Rieber H. 1962. Beobachtungen an Ammoniten aus dem Ober-Aalénien (Systematik und Ontogenie). Eclogae Geologicae Helvetiae 55:587-594.

Peer) reviewing PDF | (2020:10:54008:2:0:NEW 14 Jan 2021) 
591

592

593

594

595

596

597

598

599

600

601

602

603

604

605

606

607

608

609

610

611

612

613

614

615

616

617

618

619

620

621

622

623

624

625

626

627

628

Rohlf F. 2010. TPSDig2: A program for landmark development and analysisAvailable at: http://life.bio.sunysb.edu/morph (accessed at January 30, 2018)).

Schlager S. 2017. Morpho and Rvcg - Shape Analysis in R: R-Packages for Geometric Morphometrics, Shape Analysis and Surface Manipulations. In: Zheng G, Li S, and Székely G, eds.: Academic Press:217-256.

Silberling NJ. 1962. Stratigraphic distribution of Middle Triassic ammonites at Fossil Hill, Humboldt Range, Nevada. Journal of Paleontology 36:153-160.

Silberling NJ, and Nichols DJ. 1982. Middle Triassic molluscan fossils of biostratigraphic significance from the Humboldt Range, northwestern Nevada. US Geological Survey Professional Paper:1-77.

Simon MS, Korn D, and Koenemann S. 2010. Disparity fluctuations in Jurassic ammonoids by means of conch geometry. Palaeogeography, Palaeoclimatology, Palaeoecology 292:520-531.

Simon MS, Korn D, and Koenemann S. 2011. Temporal patterns in disparity and diversity of the Jurassic ammonoids of southern Germany. Fossil Record 14:77-94.

Smith JP. 1914. The Middle Triassic marine invertebrate faunas of North America. Washington:1-254.

Spath LF. 1934. Catalogue of the fossil Cephalopoda in the British Museum (Natural History): Part IV The Ammonoidea of the Trias. London: British Museum of Natural History:1-521.

Stone JR. 1998. Landmark based thin plate spline relative warp analysis of gastropod shells. Systematic Biology 47:254-263.

Stridsberg S. 1990. Orientation of cephalopod shells in illustrations. Palaeontology 33:243-248.

Tajika A, and Klug C. 2020. How many ontogenetic points are needed to accurately describe the ontogeny of a cephalopod conch? A case study of the modern nautilid Nautilus pompilius. PeerJ 8:e8849.

Tajika A, Morimoto N, Wani R, Naglik C, and Klug C. 2015. Intraspecific variation of phragmocone chamber volumes throughout ontogeny in the modern nautilid Nautilus and the Jurassic ammonite Normannites. PeerJ 3:e1306.

Van Bocxlaer B, and Schultheiß R. 2010. Comparison of morphometric techniques for shapes with few homologous landmarks based on machine-learning approaches to biological discrimination. Paleobiology 36:497-515.

Whiteside $\mathrm{JH}$, and Ward PD. 2011. Ammonoid diversity and disparity track episodes of chaotic carbon cycling during the early Mesozoic. Geology 39:99-102.

Wickham H. 2016. ggplot2: elegant graphics for data analysis: springer.

Zelditch ML, Swiderski DL, and Sheets HD. 2012. Geometric morphometrics for biologists: a primer. 2 ed. London, Waltham \& San Diego: Academic Press:1-478.

Peer) reviewing PDF | (2020:10:54008:2:0:NEW 14 Jan 2021) 
Figure 1

Location of the study area in NW Nevada, USA. The Fossil Hill and the Muller Canyon localities are marked. Figure adapted from (Bischof \& Lehmann 2020) ; fig. 1).

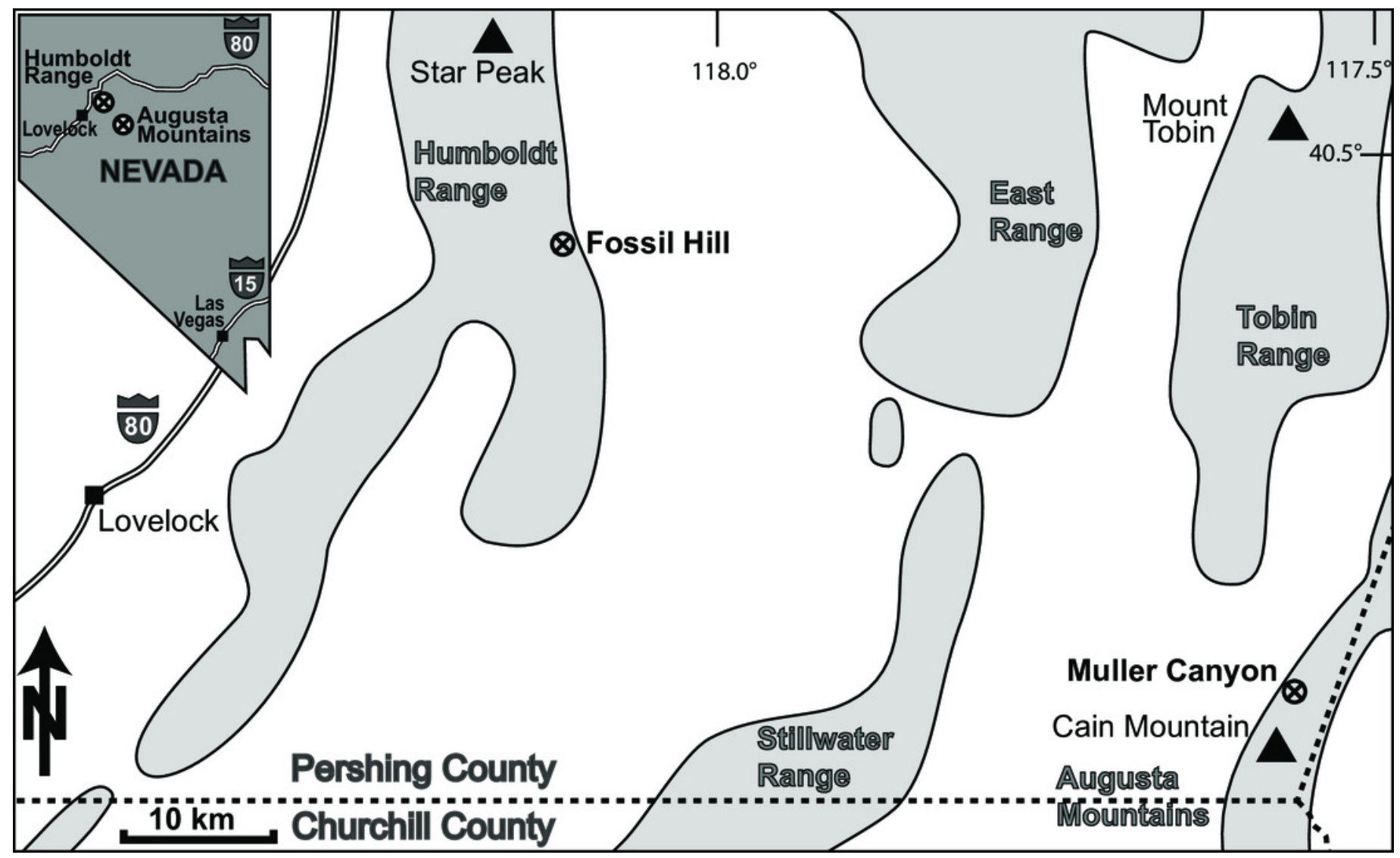




\section{Figure 2}

Biostratigraphic distribution of fossil material and synoptic lithostratigraphic sections of the outcrops in the Muller Canyon and Fossil Hill area. Stratigraphic section of Muller Canyon adapted from (Bischof \& Lehmann 2020); fig. 2).

Gray areas in stratigraphic column: Calcareous siltstone; white areas: lenticular limestone, box width refers to weathering profile. 


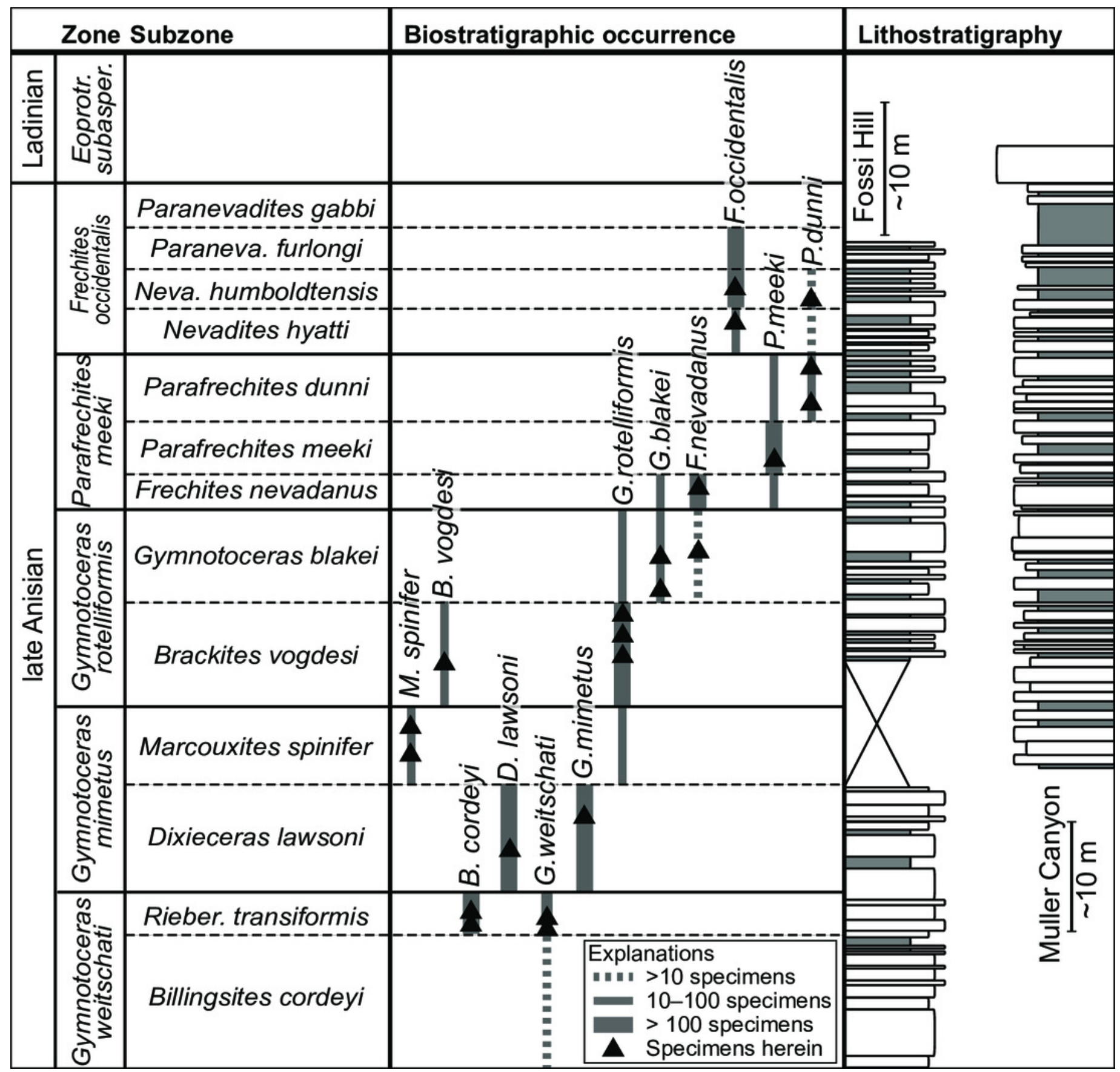




\section{Figure 3}

Ceratitid ammonoids from the Anisian (Middle Triassic) Fossil Hill Member of NW Nevada, USA.

A-D: Billingsites cordeyi Monnet \& Bucher, 2005, (A, B) GSUB C11082, (C, D) GSUB C11517;

E-H: Brackites vogdesi (Smith, 1904), (E, F) GSUB C11649, (G, H) GSUB C11646; I-L:

Dixieceras lawsoni (Smith, 1914), (I, J) GSUB C13801, (K, L) GSUB C13805; M-P: Frechites nevadanus (Mojsisovics 1888), (M, N) GSUB C12377, (O, P) GSUB C12382. 


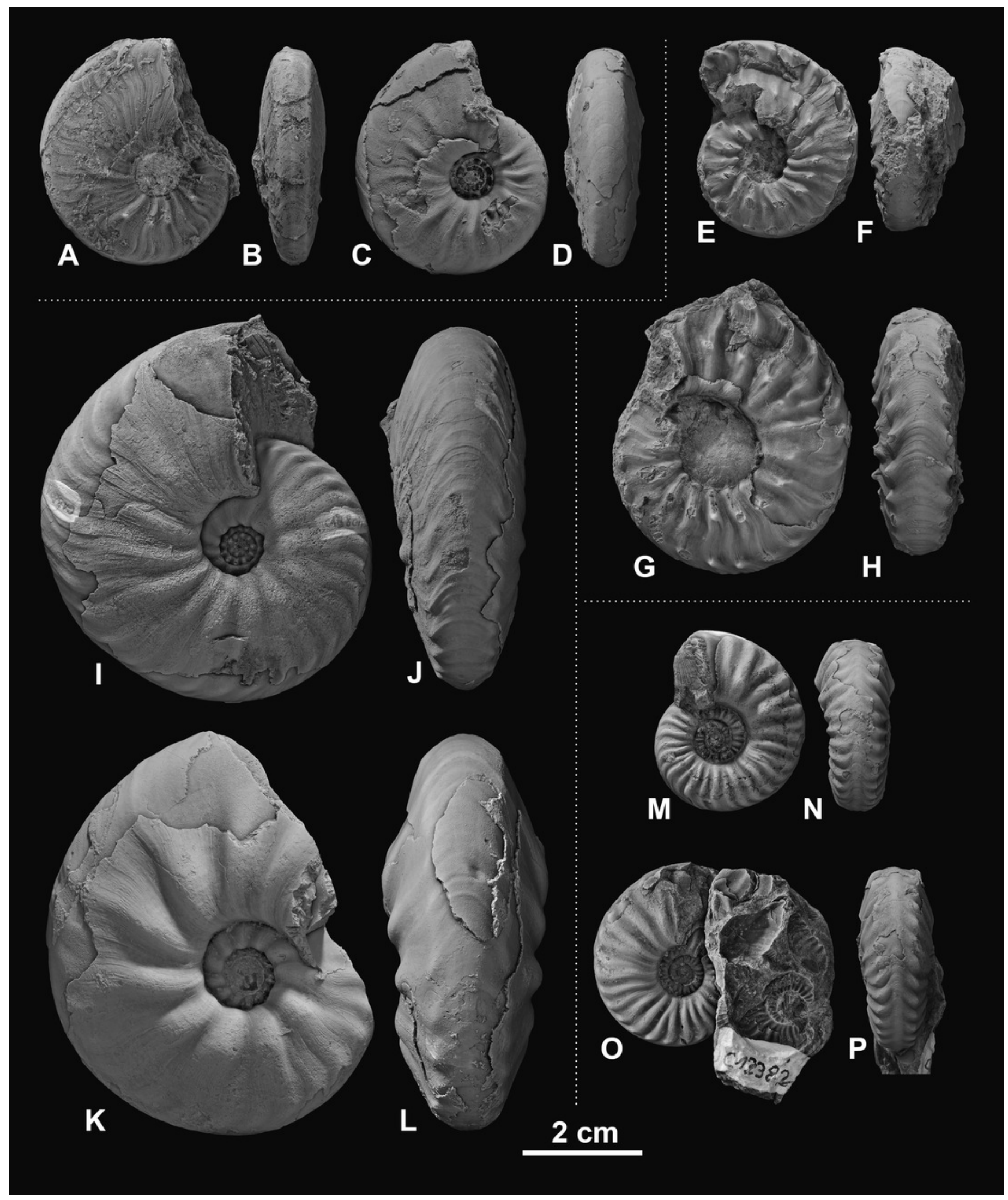


Figure 4

Ceratitid ammonoids from the Anisian (Middle Triassic) Fossil Hill Member of NW Nevada, USA.

A-D) Gymnotoceras blakei (Gabb, 1864), (A, B) GSUB C12243, (C, D) GSUB C12264; E-H: Parafrechites dunni (Smith, 1914), (E, F) GSUB C9946 (G, H) GSUB C12906; I-L: Frechites occidentalis (Smith 1914), (I, J) GSUB C8998, (K, L) GSUB C13251; M-P: Gymnotoceras rotelliformis (Meek, 1877), (M, N) GSUB C11594, (O, P) GSUB C11702. 


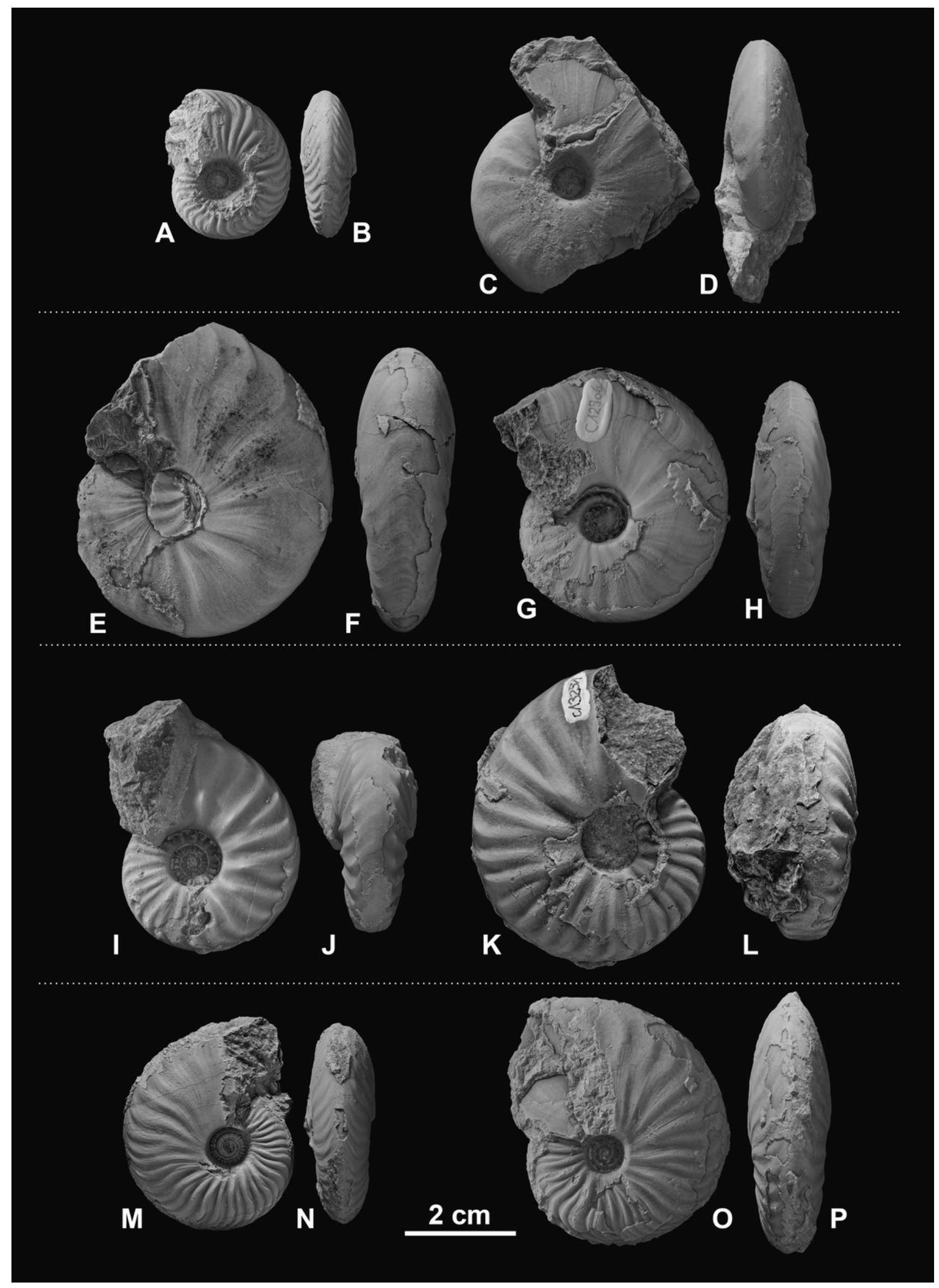




\section{Figure 5}

Ceratitid ammonoids from the Anisian (Middle Triassic) Fossil Hill Member of NW Nevada, USA.

A-E: Gymnotoceras weitschati Monnet \& Bucher 2005, (A, B) GSUB C11111, (C-E) GSUB C11158; F-J: Marcouxites spinifer (Smith, 1914), (F, G) GSUB C10050, (H-J) GSUB C10137;

K-N: Gymnotoceras mimetus Monnet \& Bucher 2005, (K, L) GSUB C15005, (M, N) GSUB C13811; O-R: Parafrechites meeki (Mojsisovics 1888), (O, P) GSUB C12534, (Q, R) GSUB C12618. 


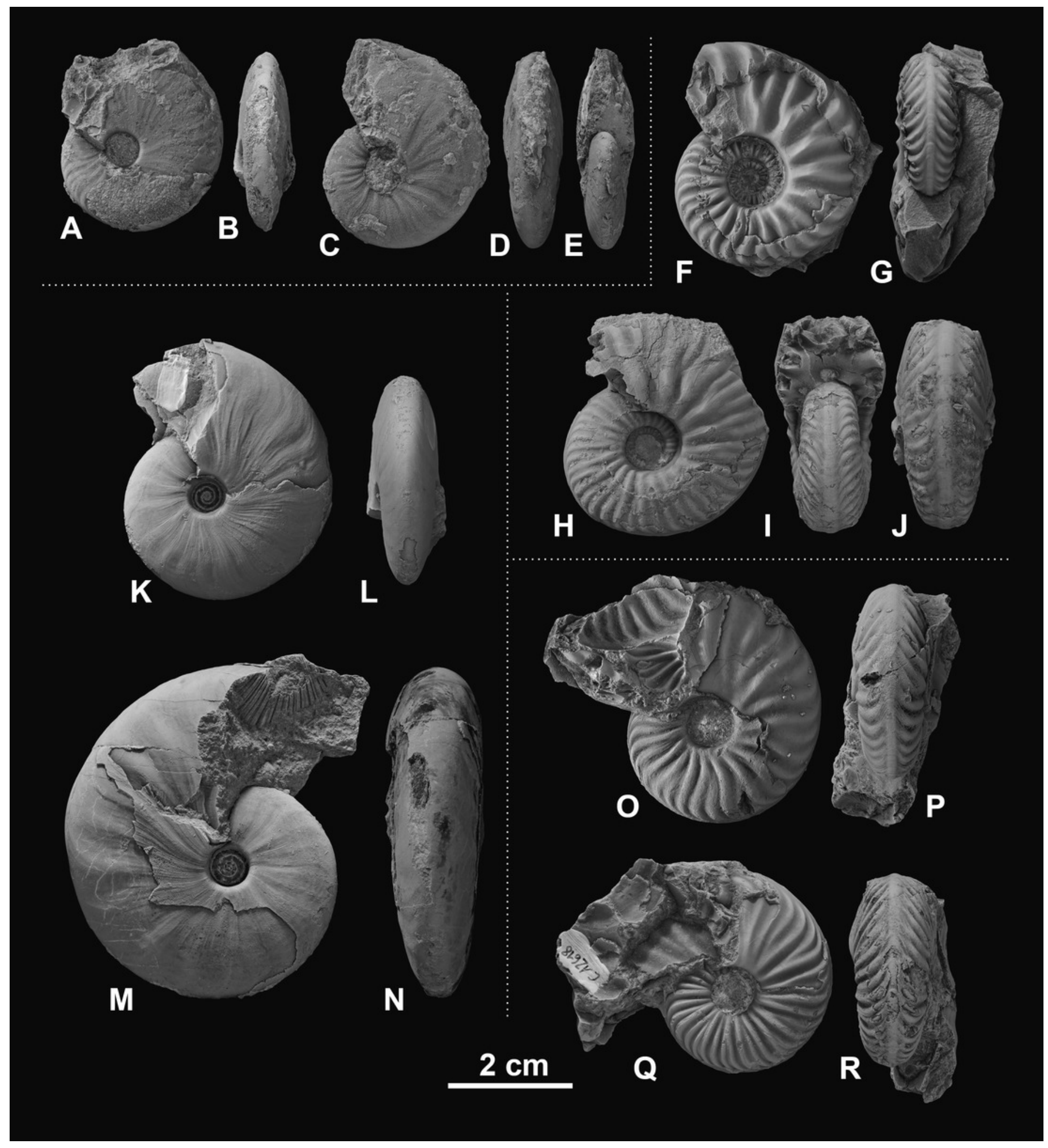




\section{Figure 6}

Digitized sketch of high-precision cross-section of an ammonoid specimen meeting the initial chamber (protoconch) with position of landmarks on last two half whorls. Filled crosses: fixed landmarks; empty crosses: sliding landmarks; black numbers: numbers

Definition of fixed landmarks: 1) venter of preceding whorl; 2) venter of whorl; 3 and 4) ventral shoulder or point of highest curvature; 5 and 6) maximum width; 7 and 8) Umbilical seam

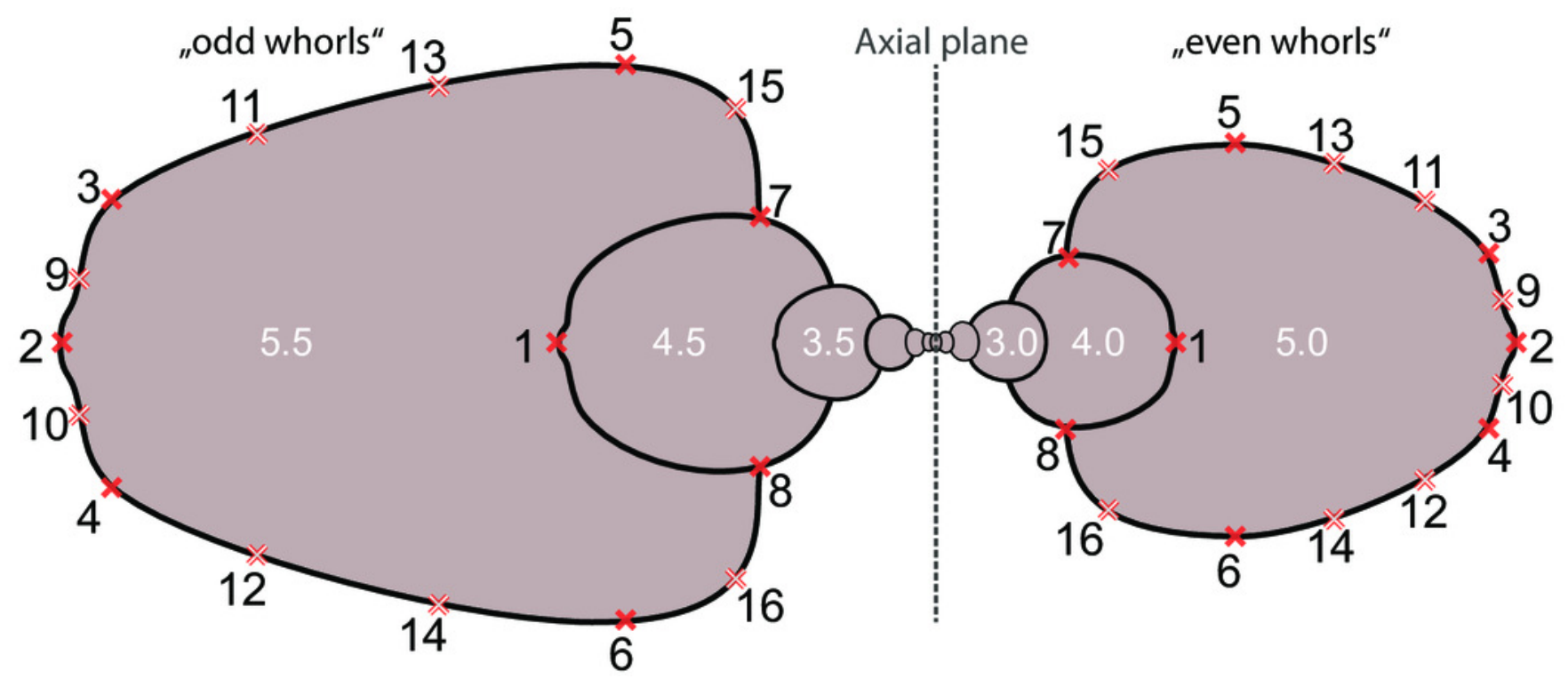


Figure 7

Ontogenetic morphospace of all species analyzed. A) Principal Component 1 and 2; B) Principal component 1 and 3.
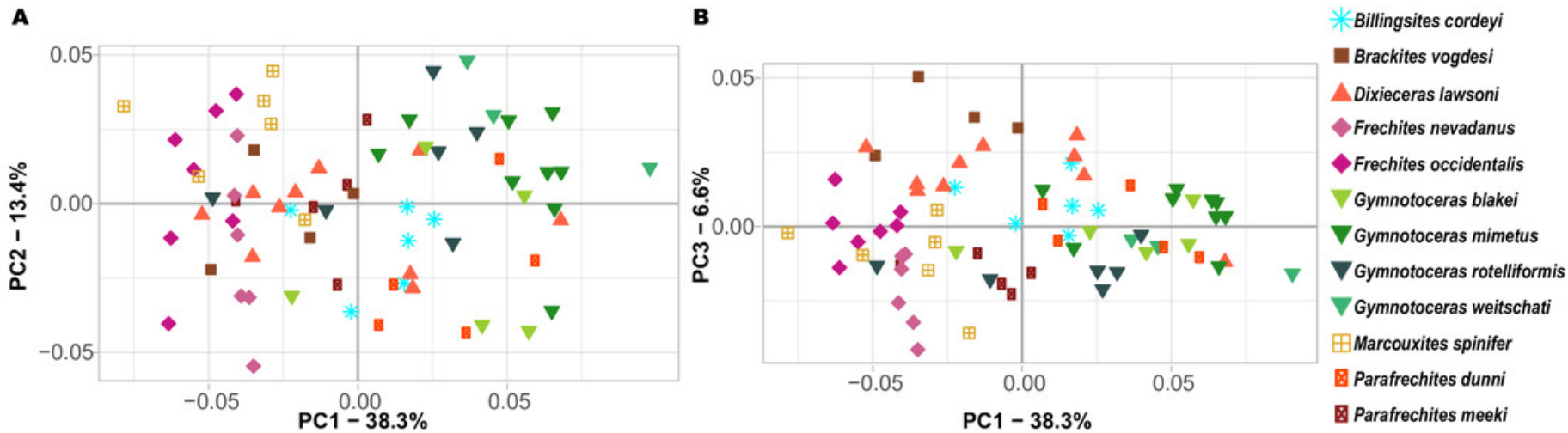
Figure 8

Developmental morphospace with PCA of Procrustes shape variables. Point size refers to whorl stage. Deformation grids of the mean shape to the modeled shapes of the extreme values for $\mathrm{PC} 1$ and $\mathrm{PC}$.

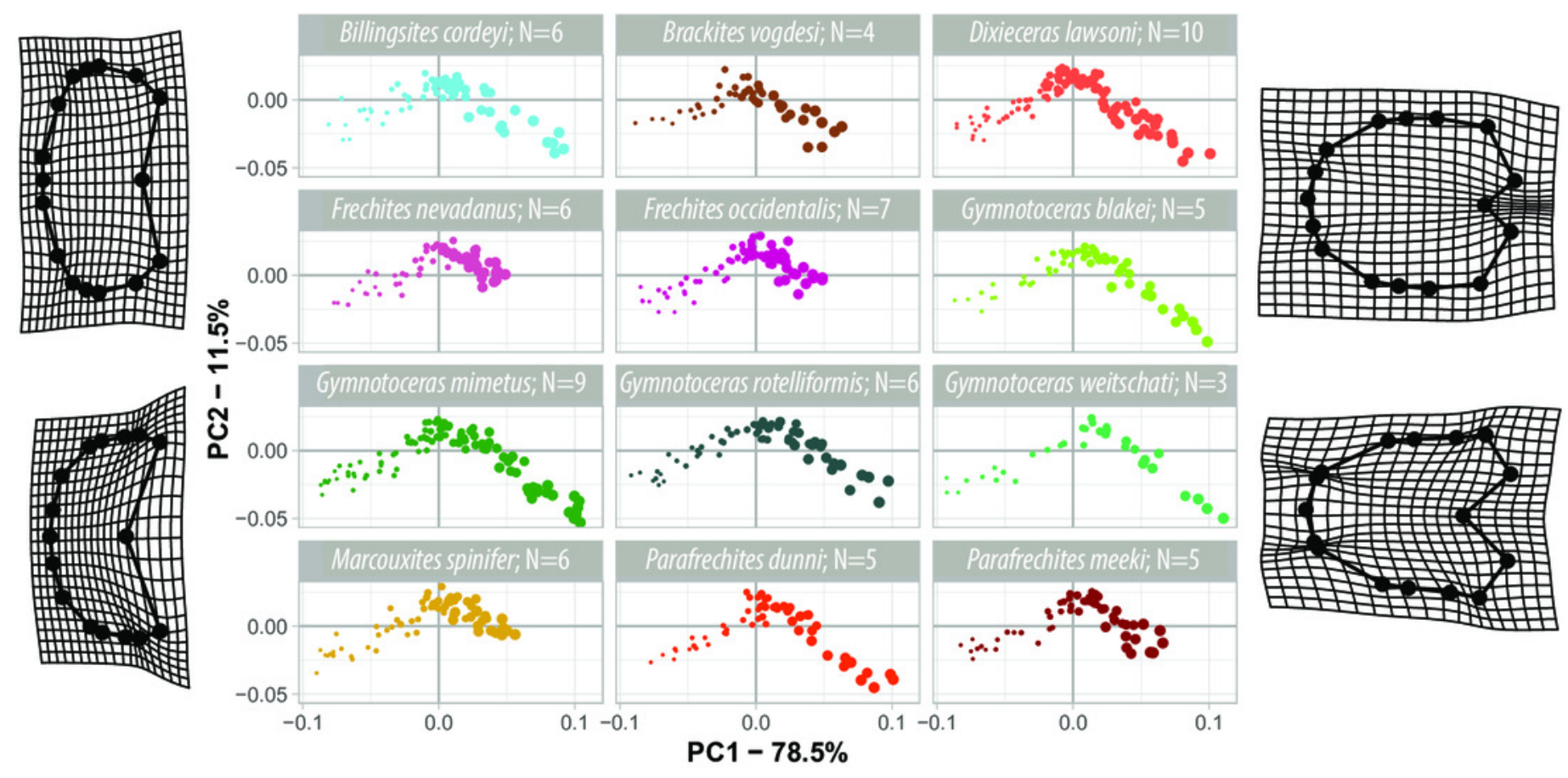


Figure 9

Mean shapes of whorl stages $0.5,3.0$ and 5.5.

Fixed landmarks are marked with a cross.

A) whorl 0.5

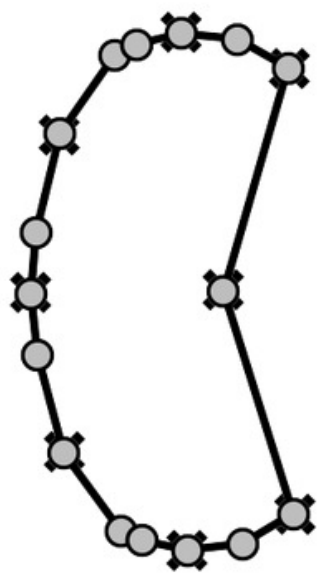

B) whorl 3.0

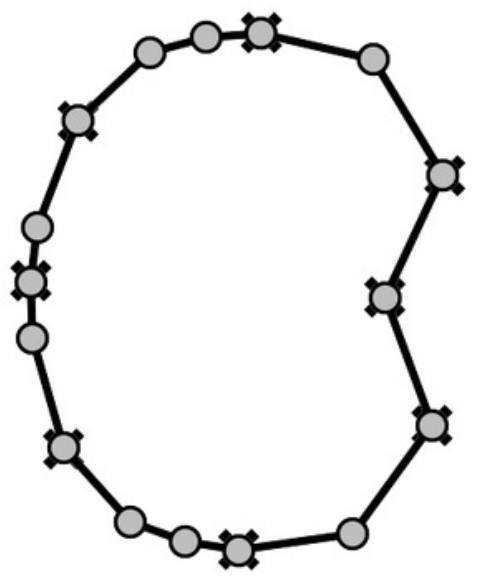

C) whorl 5.5

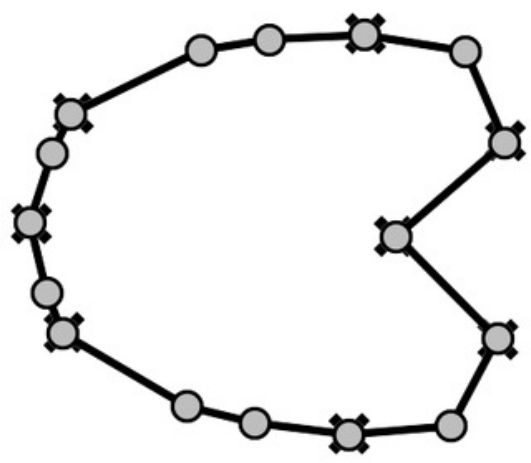


Figure 10

TPS spline of mean shape of whorl 5.5 of all species in this study (grey) plotted against the mean shape of whorl 5.5 of the respective species (black).

Fixed landmarks are marked with a cross.

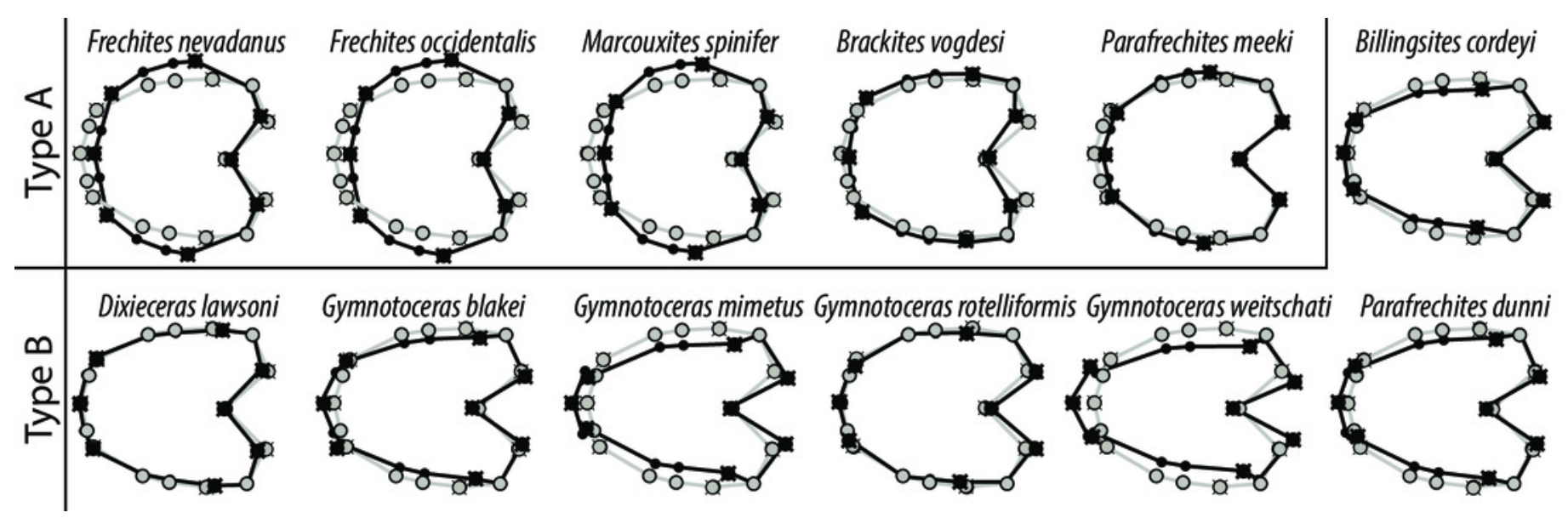


Figure 11

Developmental morphospace with PCA of weighted Procrustes shape variables. Point size refers to number of whorl stage. Deformation grids of the mean shape to the modeled shapes of the extreme values for PC1 and PC2.
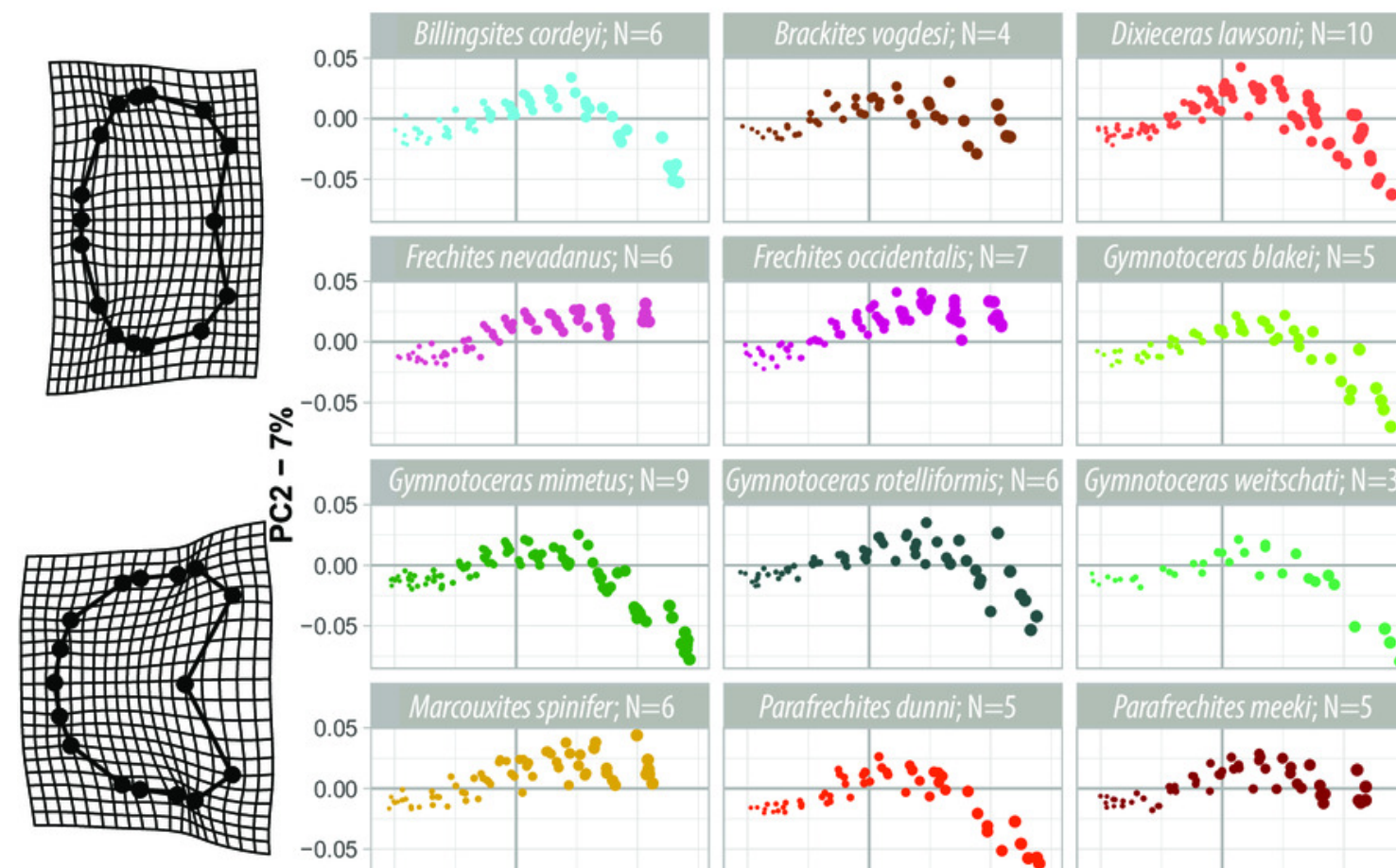

\ั
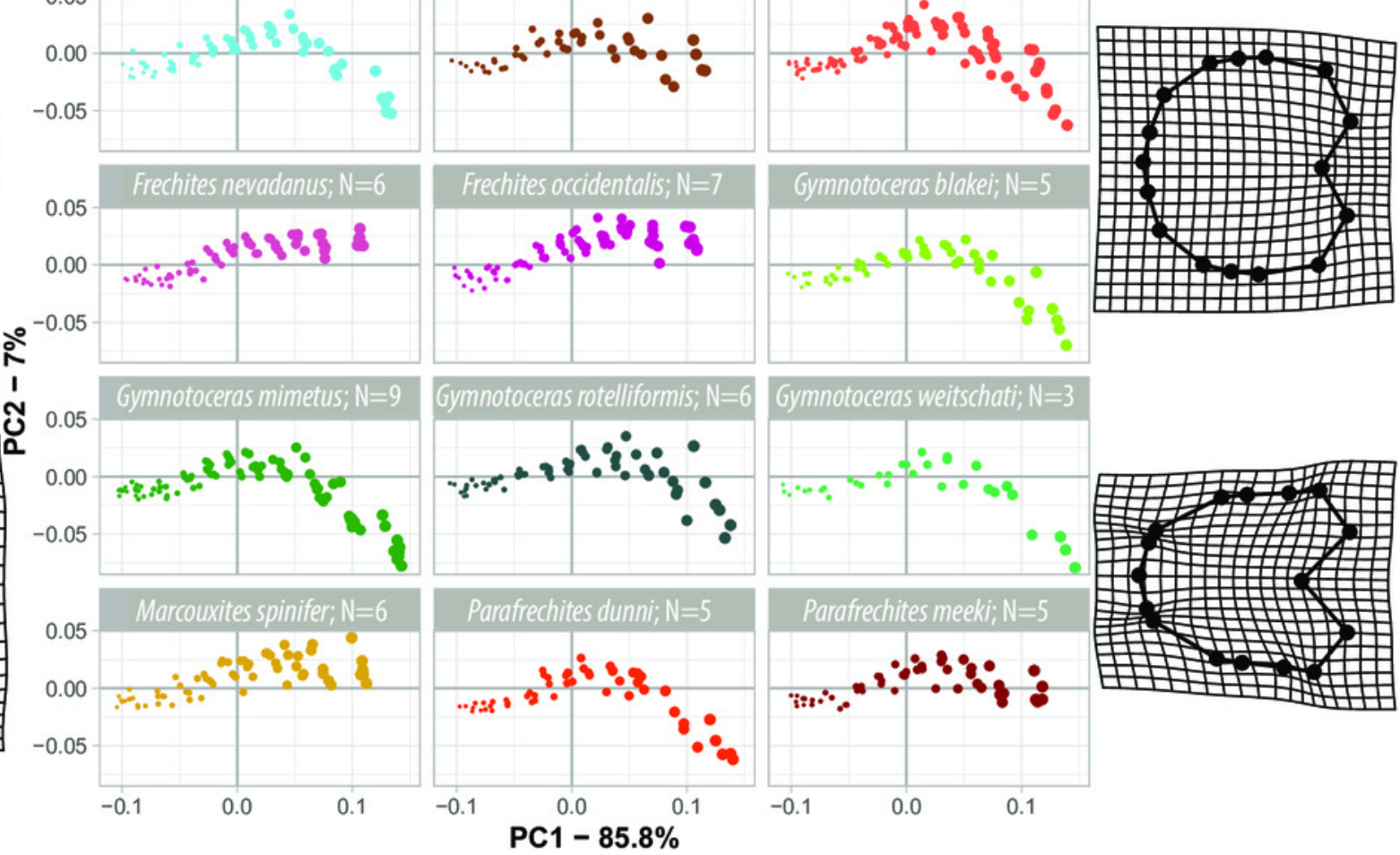


\section{Table $\mathbf{1}$ (on next page)}

Morphological comparison of the species in focus. For biostratigraphic distribution see Figure 2.

$\mathrm{N}$ : Number of specimens; U: maximum umbilical diameter; W: maximum whorl width; D: maximum diameter of conch. Measurement values and ratios based on material herein. More detailed information on the studied species was published by Silberling \& Nichols (1982) and Monnet \& Bucher (2005). 


\begin{tabular}{|c|c|c|c|c|c|c|c|c|}
\hline Species & $\mathrm{N}$ & $\begin{array}{l}\text { Total } \\
\text { number } \\
\text { of } \\
\text { volutions }\end{array}$ & $\begin{array}{l}\text { Venter and conch } \\
\text { outline }\end{array}$ & Sculpture & $\begin{array}{l}\text { Dmax } \\
{[\mathrm{mm}]}\end{array}$ & $\mathrm{U} / \mathrm{D}$ & $\mathrm{W} / \mathrm{D}$ & $\begin{array}{l}\text { Figure } \\
\text { herein }\end{array}$ \\
\hline \multicolumn{9}{|l|}{$\begin{array}{l}\text { Beyrichitinae Spath, } \\
1934\end{array}$} \\
\hline $\begin{array}{l}\text { Billingsites cordeyi } \\
\text { Monnet \& Bucher, } \\
2005\end{array}$ & 6 & $6-6.5$ & $\begin{array}{l}\text { Slightly angular ventral } \\
\text { shoulder } \\
\text { Very weak developed } \\
\text { keel }\end{array}$ & $\begin{array}{l}\text { Falcoid, prorsiradiate ribs, } \\
\text { sometimes branched } \\
\text { Nodes at branching points }\end{array}$ & 34.3 & $\begin{array}{l}\min : \\
0.17 \\
\max : \\
0.24\end{array}$ & $\begin{array}{l}\min : 0.28 \\
\max : 0.35\end{array}$ & $3 \mathrm{~A}-\mathrm{D}$ \\
\hline $\begin{array}{l}\text { Dixieceras lawsoni } \\
\text { (Smith, 1914) }\end{array}$ & 10 & $6-7$ & $\begin{array}{l}\text { Stout, discoidal outline } \\
\text { Rounded ventral } \\
\text { shoulders }\end{array}$ & $\begin{array}{l}\text { Falcoid, prorsiradiate ribs, } \\
\text { sometimes branched } \\
\text { Umbilical thickening of } \\
\text { whorls }\end{array}$ & 57.7 & $\begin{array}{l}\min : \\
0.19 \\
\max : \\
0.25\end{array}$ & $\begin{array}{l}\min : 0.23 \\
\max : 0.44\end{array}$ & $3 \mathrm{I}-\mathrm{L}$ \\
\hline $\begin{array}{l}\text { Frechites nevadanus } \\
\text { (Mojsisovics 1888) }\end{array}$ & 6 & $5.5-6$ & $\begin{array}{l}\text { Subrectangular outline } \\
\text { Clearly developed keel }\end{array}$ & $\begin{array}{l}\text { Strong, falcoid, } \\
\text { prorsiradiate ribs, } \\
\text { sometimes branched } \\
\text { Adults: Pronounced } \\
\text { tubercles at lower flank }\end{array}$ & 28.9 & $\begin{array}{l}\min : \\
0.29 \\
\max : \\
0.37\end{array}$ & $\begin{array}{l}\min : 0.39 \\
\max : 0.46\end{array}$ & $3 \mathrm{M}-\mathrm{P}$ \\
\hline $\begin{array}{l}\text { Frechites occidentalis } \\
\text { (Smith 1914) }\end{array}$ & 7 & $6-7$ & $\begin{array}{l}\text { Angular ventral } \\
\text { shoulder } \\
\text { Sometimes very weak } \\
\text { developed keel }\end{array}$ & $\begin{array}{l}\text { Strong, slightly } \\
\text { prorsiradiate ribs, some } \\
\text { rare tubercles } \\
\text { Towards maturity ribbing } \\
\text { fades }\end{array}$ & 42.6 & $\begin{array}{l}\min : \\
0.24 \\
\max : \\
0.27\end{array}$ & $\begin{array}{l}\min : 0.38 \\
\max : 0.43\end{array}$ & $4 \mathrm{I}-\mathrm{L}$ \\
\hline $\begin{array}{l}\text { Gymnotoceras blakei } \\
(\mathrm{Gabb}, 1864)\end{array}$ & 5 & $5.5-6$ & $\begin{array}{l}\text { Discoidal outline } \\
\text { Rounded ventral } \\
\text { shoulders, weak keel }\end{array}$ & $\begin{array}{l}\text { Falcoid, prorsiradiate, } \\
\text { unbranched ribs } \\
\text { Towards maturity fading } \\
\text { ribs and megastriae }\end{array}$ & 37.8 & $\begin{array}{l}\min : \\
0.15 \\
\max : \\
0.28\end{array}$ & $\begin{array}{l}\min : 0.30 \\
\max : 0.38\end{array}$ & $4 \mathrm{~A}-\mathrm{D}$ \\
\hline $\begin{array}{l}\text { Gymnotoceras mimetus } \\
\text { Monnet \& Bucher } 2005\end{array}$ & 9 & $6-6.5$ & $\begin{array}{l}\text { Discoidal to } \\
\text { subrectangular outline } \\
\text { Rounded ventral } \\
\text { shoulders, no keel }\end{array}$ & $\begin{array}{l}\text { Megastriae and weak } \\
\text { falcoid, prorsiradiate ribs, } \\
\text { slightly swelling towards } \\
\text { umbilicus }\end{array}$ & 43.0 & $\begin{array}{l}\min : \\
0.14 \\
\max : \\
0.22\end{array}$ & $\begin{array}{l}\min : 0.29 \\
\max : 0.40\end{array}$ & $5 \mathrm{~K}-\mathrm{N}$ \\
\hline
\end{tabular}




\begin{tabular}{|c|c|c|c|c|c|c|c|c|}
\hline $\begin{array}{l}\text { Gymnotoceras } \\
\text { rotelliformis (Meek, } \\
1877)\end{array}$ & 6 & 6 & $\begin{array}{l}\text { Stout discoidal outline, } \\
\text { very weak keel } \\
\text { Rounded ventral } \\
\text { shoulders }\end{array}$ & $\begin{array}{l}\text { Regular, slightly } \\
\text { prorsiradiate ribs } \\
\text { Towards maturity ribbing } \\
\text { slightly fades }\end{array}$ & 34.3 & $\begin{array}{l}\min : \\
0.17 \\
\max : \\
0.26\end{array}$ & $\begin{array}{l}\min : 0.32 \\
\max : 0.38\end{array}$ & $4 \mathrm{M}-\mathrm{P}$ \\
\hline $\begin{array}{l}\text { Gymnotoceras } \\
\text { weitschati Monnet \& } \\
\text { Bucher } 2005\end{array}$ & 3 & 6 & $\begin{array}{l}\text { Compressed, discoidal } \\
\text { outline } \\
\text { Perfectly rounded } \\
\text { shoulders, no keel }\end{array}$ & $\begin{array}{l}\text { Megastriae and weak } \\
\text { falcoid, prorsiradiate ribs, } \\
\text { slightly swelling towards } \\
\text { umbilicus }\end{array}$ & 28.4 & $\begin{array}{l}\min : \\
0.17 \\
\max : \\
0.20\end{array}$ & $\begin{array}{l}\min : 0.29 \\
\max : 0.33\end{array}$ & $5 \mathrm{~A}-\mathrm{E}$ \\
\hline $\begin{array}{l}\text { Parafrechites dunni } \\
\text { (Smith, 1914) }\end{array}$ & 5 & $5.5-6.5$ & $\begin{array}{l}\text { Stout discoidal outline, } \\
\text { sometimes keel } \\
\text { Rounded to subangular } \\
\text { ventral shoulders }\end{array}$ & $\begin{array}{l}\text { Regular but weak, slightly } \\
\text { prorsiradiate ribs } \\
\text { Towards maturity ribbing } \\
\text { slightly fades }\end{array}$ & 35.2 & $\begin{array}{l}\min : \\
0.18 \\
\max : \\
0.20\end{array}$ & $\begin{array}{l}\min : 0.31 \\
\max : 0.42\end{array}$ & $4 \mathrm{E}-\mathrm{H}$ \\
\hline $\begin{array}{l}\text { Parafrechites meeki } \\
\text { (Mojsisovics 1888) }\end{array}$ & 5 & $5.5-6$ & $\begin{array}{l}\text { Subrectangular outline } \\
\text { Strong keel, sub- } \\
\text { angular shoulders }\end{array}$ & $\begin{array}{l}\text { Strong and regular, } \\
\text { falcoid, prorsiradiate ribs, } \\
\text { sometimes branched }\end{array}$ & 32.1 & $\begin{array}{l}\min : \\
0.22 \\
\max : \\
0.27\end{array}$ & $\begin{array}{l}\min : 0.34 \\
\max : 0.41\end{array}$ & $5 \mathrm{O}-\mathrm{R}$ \\
\hline $\begin{array}{l}\text { Paraceratitinae } \\
\text { Silberling, } 1962\end{array}$ & & & & & & & & \\
\hline $\begin{array}{l}\text { Brackites vogdesi } \\
\text { (Smith, 1904) }\end{array}$ & 4 & $6-7$ & $\begin{array}{l}\text { Subrectangular outline, } \\
\text { slightly rounded } \\
\text { shoulders }\end{array}$ & $\begin{array}{l}\text { Regular, falcoid, } \\
\text { branched, prorsiradiate } \\
\text { ribs } \\
\text { Tubercles at brancing } \\
\text { point }\end{array}$ & 29.6 & $\begin{array}{l}\min : \\
0.28 \\
\max : \\
0.37\end{array}$ & $\begin{array}{l}\min : 0.35 \\
\max : 0.37\end{array}$ & $3 \mathrm{E}-\mathrm{H}$ \\
\hline $\begin{array}{l}\text { Marcouxites spinifer } \\
\text { (Smith, 1914) }\end{array}$ & 6 & $5.5-6$ & $\begin{array}{l}\text { Subrectangular outline, } \\
\text { angular shoulder } \\
\text { Clearly developed keel }\end{array}$ & $\begin{array}{l}\text { Strong and regular, } \\
\text { falcoid, prorsiradiate ribs } \\
\text { Tubercles and spines at } \\
\text { branching point }\end{array}$ & 25.8 & $\begin{array}{l}\min : \\
0.26 \\
\max : \\
0.36\end{array}$ & $\begin{array}{l}\min : 0.38 \\
\max : 0.42\end{array}$ & $5 \mathrm{~F}-\mathrm{J}$ \\
\hline
\end{tabular}




\section{Table 2 (on next page)}

Comparison of most important characteristics of weighted and non-weighted approaches to combine landmark configurations.

o.s.: ontogenetic stages (i.e. whorls). 


\begin{tabular}{|c|c|c|c|}
\hline $\begin{array}{l}\text { Shape } \\
\text { variables }\end{array}$ & Effect on shape data set & Advantages & Disadvantages \\
\hline $\begin{array}{l}\text { non- } \\
\text { weighted } \\
\text { (wPCA) }\end{array}$ & $\begin{array}{l}\text { - Minimizes shape } \\
\text { difference between all } \\
\text { configurations of all o.s. }\end{array}$ & $\begin{array}{l}\text { - No perturbation of original } \\
\text { dataset }\end{array}$ & $\begin{array}{l}\text { - Overestimation of } \\
\text { deviations of earliest/small } \\
\text { earliest/smallest o.s. and } \\
\text { underestimation of } \\
\text { latest/largest o.s. }\end{array}$ \\
\hline $\begin{array}{l}\text { weighted } \\
\text { (wPCA) }\end{array}$ & $\begin{array}{l}\text { - Adds allometric/size } \\
\text { information to analysis } \\
\text { - Maximizes shape } \\
\text { differences between o.s. } \\
\text { - Minimizes shape } \\
\text { differences within an o.s. }\end{array}$ & $\begin{array}{l}\text { More complicated } \\
\text { computation than other } \\
\text { methods } \\
\text { - Deviations of } \\
\text { earliest/smallest o.s. } \\
\text { whorls less overestimated } \\
\text { and of latest/large o.s. less } \\
\text { underestimated }\end{array}$ & 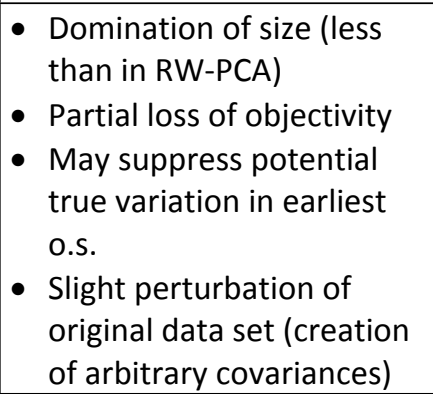 \\
\hline $\begin{array}{l}\text { shape-size } \\
\text { space } \\
\text { (RW-PCA) }\end{array}$ & $\begin{array}{l}\text { - Adds allometric/size } \\
\text { information to analysis } \\
\text { - Every configuration is } \\
\text { scaled individually } \\
\text { according to their centroid } \\
\text { size }\end{array}$ & $\begin{array}{l}\text { - Easy to compute } \\
\text { - Intuitive }\end{array}$ & $\begin{array}{l}\text { - Extreme domination of } \\
\text { size } \\
\text { - Strong perturbation of } \\
\text { original data set, cannot } \\
\text { be used for most } \\
\text { subsequent analyses }\end{array}$ \\
\hline
\end{tabular}




\section{Table 3(on next page)}

Summary and explanation on the three different ontogenetic types. Heterochronic terms as defined by McNamara (2012). 


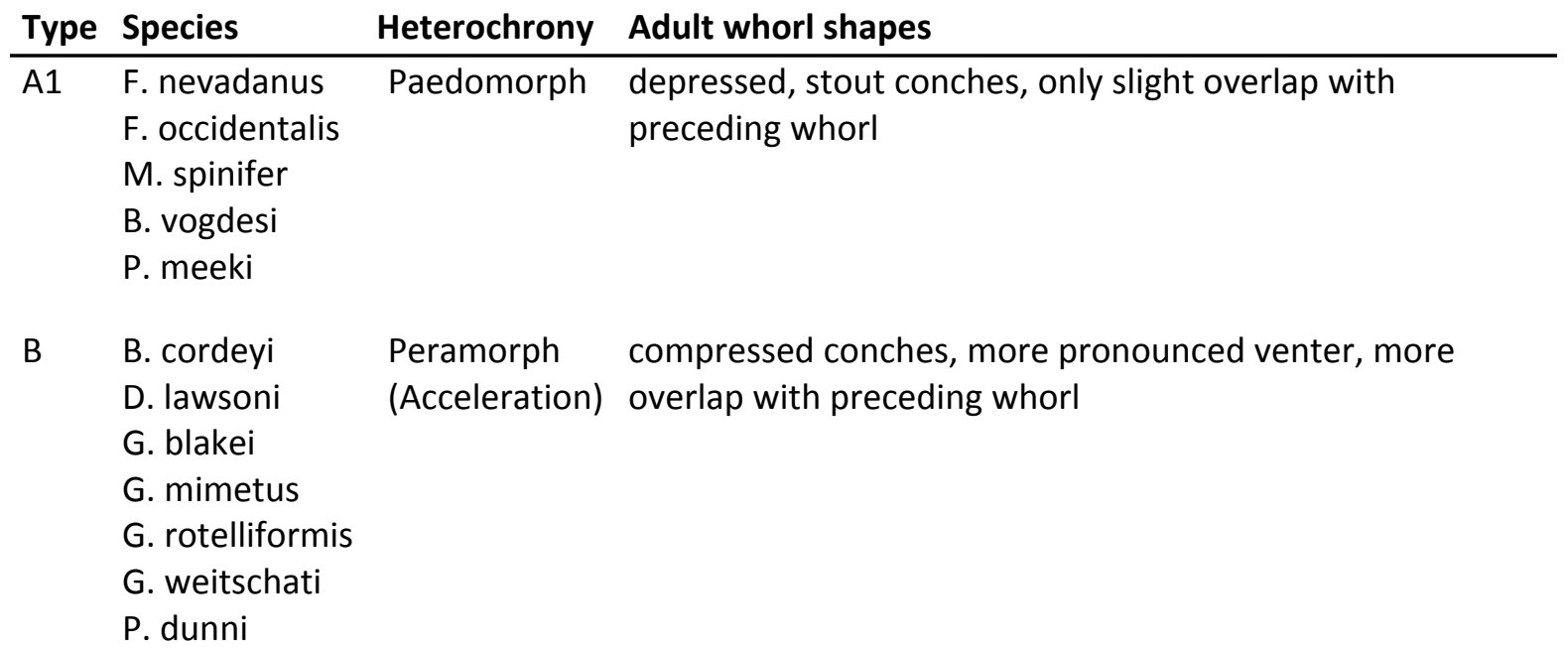

